\title{
Immune Modulation by Androgen Deprivation and Radiation Therapy: Implications for Prostate Cancer Immunotherapy
}

\author{
Jennifer L. Kalina ${ }^{1}$, David S. Neilson ${ }^{1,2}$, Alexandra P. Comber ${ }^{1,2}$, Jennifer M. Rauw ${ }^{3,4}$, \\ Abraham S. Alexander ${ }^{3,5}$, Joanna Vergidis ${ }^{3,4}$ and Julian J. Lum ${ }^{1,2, *}$ \\ 1 Trev and Joyce Deeley Research Centre, British Columbia Cancer Agency, Victoria, BC V8R 6V5, Canada; \\ Jennifer.Kalina@bccancer.bc.ca (J.L.K.); dneilson@bccrc.ca (D.S.N.); acomber@bccrc.ca (A.P.C.) \\ 2 Department of Biochemistry \& Microbiology, University of Victoria, Victoria, BC V8P 5C2, Canada \\ 3 British Columbia Cancer Agency, Victoria, BC V8R 6V5, Canada; Jennifer.Rauw@bccancer.bc.ca (J.M.R.); \\ AAlexander3@bccancer.bc.ca (A.S.A.); JVergidis@bccancer.bc.ca (J.V.) \\ 4 Department of Medicine, University of British Columbia, Vancouver, BC V5Z 1M9, Canada \\ 5 Department of Surgery, University of British Columbia, Vancouver, BC V5Z 1M9, Canada \\ * Correspondence: jjlum@bccancer.bc.ca; Tel.: +1-250-519-5700
}

Academic Editor: Samuel C. Mok

Received: 3 December 2016; Accepted: 20 January 2017; Published: 27 January 2017

\begin{abstract}
Prostate cancer patients often receive androgen deprivation therapy (ADT) in combination with radiation therapy (RT). Recent evidence suggests that both ADT and RT have immune modulatory properties. First, ADT can cause infiltration of lymphocytes into the prostate, although it remains unclear whether the influx of lymphocytes is beneficial, particularly with the advent of new classes of androgen blockers. Second, in rare cases, radiation can elicit immune responses that mediate regression of metastatic lesions lying outside the field of radiation, a phenomenon known as the abscopal response. In light of these findings, there is emerging interest in exploiting any potential synergy between ADT, RT, and immunotherapy. Here, we provide a comprehensive review of the rationale behind combining immunotherapy with $\mathrm{ADT}$ and RT for the treatment of prostate cancer, including an examination of the current clinical trials that employ this combination. The reported outcomes of several trials demonstrate the promise of this combination strategy; however, further scrutiny is needed to elucidate how these standard therapies interact with immune modulators. In addition, we discuss the importance of synchronizing immune modulation relative to ADT and RT, and provide insight into elements that may impact the ability to achieve maximum synergy between these treatments.
\end{abstract}

Keywords: androgen deprivation therapy; radiation therapy; immunotherapy; prostate cancer; cancer vaccines; checkpoint inhibitors

\section{Introduction}

In the 1940s, prostate cancers ( $\mathrm{PCa}$ ) were found to have a unique dependence on androgens. This discovery led to the emergence of a new approach to treat PCa using androgen deprivation therapy (ADT) [1]. Moreover, there is marked improvement in tumor control when ADT is combined with radiation therapy (RT), particularly for localized disease [2]. For many years, ADT and RT were presumed to work through a direct cytotoxic action on tumors; however, recent studies have uncovered under-appreciated benefits of these treatments on the immune system. In this review, we discuss current strategies in ADT and RT, the role each plays during the development of anti-tumor immune responses and the rationale for combining these standard therapies with immune modulation. We also 
summarize the current state of early clinical trials involving combinatorial strategies with ADT, RT, and immunotherapy and highlight important considerations for future trial design.

\section{Standard Treatment Options for Prostate Cancer}

Standard and potentially curative treatment options for localized PCa are typically determined based on risk grouping [3-5]. In recent years, there has been a shift toward active surveillance for men with low risk disease given the low disease-specific mortality observed in recent randomized trials [6,7]; however, active treatment may still be appropriate for some patients, especially those of a younger age. On the other hand, active treatment is felt to improve outcomes for men with intermediate or high risk disease $[6,8,9]$. Standard options for intermediate risk disease include radical prostatectomy, brachytherapy, and external beam radiotherapy (EBRT), with, or without, ADT [10]. Typical options for high risk disease include surgery (with or without adjuvant RT), EBRT and ADT, or EBRT and ADT with brachytherapy boost [10]. In addition, prostate stereotactic ablative radiotherapy (SABR) is an emerging modality that appears effective [11,12], although additional studies are needed to validate these early but promising findings.

\subsection{Androgen Receptor Signaling in Prostate Cancer}

The androgen receptor (AR) is a nuclear hormone receptor activated by engagement of its ligands, testosterone and dihydrotestosterone (DHT). Ligand binding results in the displacement of heat shock proteins and exposes the AR nuclear localization signal. In the nucleus, the receptor dimerizes and binds to androgen response elements (AREs) in the promoter regions of target genes (e.g., PSA (prostate-specific antigen)) [13]. Additional co-regulatory proteins are recruited to facilitate transcription, leading to downstream cellular responses such as growth and survival [14]. Androgens and the AR are the main regulators of PCa cell growth. Thus, androgen ablation therapies repress transcription of AR target genes, which causes activation of tumor cell apoptosis and the eradication of a large fraction of androgen-dependent cancer cells [15].

PCa regression and disease stability will often occur with ADT; however, disease progression is inevitable in patients with metastatic disease at presentation. PCa growth despite adequate first line ADT (defined by a castrate serum-free testosterone level) is described as castration-resistant prostate cancer (CRPC). Mechanisms of PCa progression in the setting of ADT are multifactorial. Metastatic $\mathrm{PCa}$ is a heterogeneous mix of both androgen-dependent and androgen-independent malignant cells. Continuous treatment with ADT will remove the larger population of androgen-dependent cells but allows for the selective outgrowth of androgen-independent cells. In addition, reactivation of AR signaling has been identified as an important driver in androgen resistance [16]. The loss of response to ADT is associated with post-castration activation of the AR via mechanisms such as AR mutation, gene amplification, incomplete blockade of ligand-dependent AR activation, and aberrant AR co-regulator activity [14]. Therefore, the AR plays an important role in both the castrate-sensitive and castration-resistant setting. 


\subsection{Current Strategies for $A D T$}

ADT can be accomplished with either bilateral orchiectomy or medical castration using either gonadotrophin releasing hormone $(\mathrm{GnRH})$ agonists or antagonists. These approaches are often combined with first-generation anti-androgen therapies, such as flutamide, bicalutamide, and nilutamide, to achieve total androgen blockage by inhibiting the effects of androgen production from the adrenal gland. For metastatic castration-sensitive disease, ADT is the standard approach [17] and superior outcomes may be achieved if ADT is combined with docetaxel chemotherapy $[18,19]$. For most patients, ADT is initially effective; however, despite these efforts a significant proportion of patients ultimately experience disease recurrence and progression to castration-resistant PCa [20].

Since the introduction of docetaxel in 2004, treatment options for metastatic castration-resistant prostate cancer (mCRPC) have changed dramatically. Several newer agents have been developed for mCRPC that demonstrate enhanced overall survival when given in conjunction with continued ADT. These so called "next-generation" strategies include drugs that interfere with androgenic stimulation, such as abiraterone and enzalutamide, as well as chemotherapy (e.g., docetaxel and cabazitaxel). Abiraterone is an irreversible inhibitor of cytochrome P450 17A1, which impairs androgen-receptor signaling by depleting both adrenal and intra-tumoral androgens. Abiraterone is often administered in conjunction with prednisone to counteract side effects related to compensatory adrenocorticotropic hormone $(\mathrm{ACTH})$ production. Indeed, abiraterone plus prednisone extended overall survival, compared to prednisone alone, in two landmark phase III studies involving both chemotherapy-naïve CRPC, as well as men previously treated with docetaxel [21,22]. Similarly, enzalutamide, a competitive inhibitor of the AR, was shown to prolong overall survival compared to placebo in both chemotherapy-naïve and docetaxel-treated CRPC [23,24]. Despite some improvement in survival, these strategies ultimately are not curative. Thus, there remains a need for more effective approaches to treat men with mCRPC. In addition, many of these newer approaches have not yet been systematically compared in randomized trials, leaving several unanswered questions regarding the optimal selection, sequencing, and combination with other therapies including RT and immune modulation. For the purposes of this review, we have collectively used the term ADT to describe both anti-androgen and androgen deprivation techniques. While each has distinct physiological mechanisms of action, the main goal of these interventions is to halt PCa growth by inhibiting the androgen-AR axis.

\subsection{The Role of RT in Prostate Cancer}

\subsubsection{Curative Treatment for Localized Disease}

RT is well established as an effective and potentially curative treatment for localized PCa, either alone or in conjunction with ADT [10]. Prostate RT can be delivered using EBRT or brachytherapy. Modern EBRT is typically administered as intensity modulated radiotherapy (IMRT) or volumetric modulated arc therapy (VMAT), in which multiple beams or arcs, each varying in intensity, are used to deliver high doses to the prostate while minimizing exposure to normal tissues. IMRT has been shown to significantly reduce both gastrointestinal and genitourinary toxicity compared to 3D conformal radiotherapy [25]. Image guidance through the use of fiducial markers, cone beam CT, or ultrasound can also be applied to further reduce treatment-related morbidity [26,27]. These techniques allow for RT dose escalation, which has been shown to improve biochemical disease-free survival [28-30]. Brachytherapy, in which radioactive seeds are placed within the gland either permanently or temporarily, can also be used to deliver highly conformal radiation doses to the prostate with excellent outcomes [31]. For higher risk disease, EBRT is often combined with a brachytherapy boost, providing a form of dose escalation with high rates of biochemical disease control [32,33]. 


\subsubsection{Palliative Treatment}

$\mathrm{RT}$ also plays a major role in the palliative management of PCa in the metastatic, recurrent, or castration-resistant setting. Palliative EBRT is effective for treating symptoms from painful bony metastases [34] and has utility in the treatment of malignant spinal cord compression [35]. RT can also be useful for palliation of a variety of other local symptoms such as hematuria, hemoptysis, or painful soft tissue masses. Palliative pelvic RT can be useful in maintaining local control for prostate masses with potential for bladder or rectal invasion. In the setting of metastatic PCa, there is also emerging evidence that radical treatment of the primary tumor may confer survival benefit when given along with ADT or chemotherapy [36-38]. Radium-223 is a recent addition to the armamentarium for mCRPC. This radionuclide is a systemic bone-targeted calcium mimetic that is incorporated into areas of high bone turnover, such as in osteoblastic metastases [39]. This short-range form of radiation is able to treat local PCa cells while preserving nearby normal tissue, such as bone marrow. The pivotal Alpharadin in Symptomatic Prostate Cancer (ALSYMPCA) trial demonstrated improvements in overall survival, freedom from symptomatic skeletal events, pain control, and quality of life for radium-223 over placebo [40]. These data have led to its consideration as a standard treatment option for CRPC.

\subsubsection{Stereotactic RT for Oligometastatic Disease}

There has been recent interest in the potential role of aggressive metastasis-directed therapy in the setting of "oligometastatic" or "oligo-recurrent" PCa, defined as few $(\leq 5)$ metastatic lesions [41]. It is hypothesized that metastatic cancers with a low number of lesions may represent a state of "restricted metastatic potential" [41]. If so, definitive therapy directed at identifiable metastases may improve survival or delay the need for further systemic therapies. Under this strategy, RT is delivered to all metastatic lesions using a highly accurate, conformal, image-guided technique called stereotactic radiotherapy (SABR). With this technique, large "ablative" doses of radiation are delivered in a small number of fractions (typically less than five). Early data suggests this approach yields excellent control of metastatic lesions with encouraging rates of distant-, biochemical-, ADT-free, and overall survival [41-44]. Although this approach appears promising, validation in randomized controlled trials is required.

\subsection{Combined $A D T$ and $R T$}

The combination of ADT and RT has been shown to improve overall, metastasis-free, prostate cancer-specific, and biochemical survival over RT alone for patients with intermediate to high risk and locally advanced PCa in a number of large, randomized trials [2,45-49]. For intermediate risk disease, 4-6 months of ADT appears sufficient to provide survival benefit [50,51]. For high-risk and locally-advanced disease, the optimal ADT duration is unknown, but regimens ranging from 18 to 36 months all appear effective and are commonly utilized [52-54]. The RT component of the combination is critical, with randomized evidence of inferior overall, prostate cancer-specific, and metastasis-free survival with ADT alone in high risk disease [55-57]. Two recent trials have also demonstrated clinical benefit with the addition of ADT to salvage RT in the treatment of biochemical relapse after primary surgery $[58,59]$. 
The addition of ADT to RT appears to improve outcomes by enhancing both local and distant disease control. Mechanisms of synergy are poorly understood, but are likely mediated by the AR. There are a number of possible ways by which ADT and RT improve disease control. For example, emerging data suggests that ADT can act as a "radiosensitizer" by inhibiting the tumor cell's ability to repair double-stranded DNA damage [60,61]. Milosevic et al. [62] demonstrated that ADT reduces intraprostatic hypoxia. Hypoxia is associated with poor local control and biochemical failure after RT $[63,64]$. There is also evidence that improved local and distant control could be mediated by permanent cell cycle arrest or apoptosis induced by combined treatment [65]. Finally, enhanced immune responses have also been implicated in the synergy between ADT and RT [66-68], a mechanism that could underlie both local and systemic disease control.

\section{The Immune Landscape in Prostate Cancer}

There is a general consensus that the presence of tumor infiltrating lymphocytes (TIL) is associated with better patient outcomes; however, TIL responses are often weak or absent in PCa $[69,70]$. This might be due to the prostate gland itself, which has traditionally been considered an immunologically privileged site due to the lack of afferent lymphatics and the immunosuppressive properties of semen [71]. Despite this, when T cell infiltrates are present, they are often found at a lower density than in adjacent normal or hyperplastic regions, suggesting a non-permissive or inhospitable tumor microenvironment [69]. Instead, prostate tumors commonly contain elevated levels of CD4+ and CD8+ T cells with regulatory phenotypes (e.g., expression of CD25, FoxP3, CITR, ICOS) [72-74]. In addition, the frequency of infiltrating CD4+ T regulatory ( $\mathrm{T}$ reg) cells is greater than what is often observed in classically immunogenic tumors, such as melanoma. Consistent with these findings, the prognostic significance of TIL in PCa remains controversial. Some studies show that TIL are associated with improved survival [75-77], while others describe no prognostic significance [71,77-79] or even negative associations with clinical outcome $[76,77,80,81]$. In general, it appears that PCa may not follow the trends related to the benefits of TIL as in other tumor types, likely because these TIL may be skewed towards more immunosuppressive phenotypes [72,73,82]. A tumor's "immunological status" is of great importance when considering how to best enhance these responses with immunotherapies. In the next section, we consider some of the driving mechanisms that may play crucial roles in dictating how the immune system responds to PCa.

\section{Mechanisms of Tumor Immune Evasion}

\subsection{Immune Camouflage}

Continuous pressure from the immune system provides a selective mechanism for tumor evolution and immune evasion. For example, many PCa display abnormalities in Major Histocompatibility (MHC) Class I antigen processing machinery, including low levels of surface MHC [83]. In addition, compared to other solid tumors, PCa have a relatively low mutational load [84] which may render them less responsive to checkpoint therapies that rely on pre-existing antigen-specific $\mathrm{T}$ cells for their efficacy.

\subsection{Immune Checkpoints}

$\mathrm{T}$ cell activation is regulated by an intrinsic negative feedback loop involving the B7H family receptors and ligands. This is illustrated by two widely studied pathways which have become focal points for current approaches utilizing the immune system for cancer treatment. The first identified was CTL-associated antigen-4 (CTLA-4), which competes with CD28 for binding of co-stimulatory molecules (CD80/86) on antigen presenting cells, resulting in suppression of $\mathrm{T}$ cell activation [85]. Second, programmed cell death-1 (PD-1) is expressed on activated T cells, while its ligands, PD-L1 and PD-L2, are widely expressed in many non-lymphoid tissues, including tumors [85-87]. Engagement of PD-1 by its ligand induces a state of $\mathrm{T}$ cell exhaustion characterized by suppression of effector 
cytokine production and reduced proliferative capacity [86]. Physiologically, this system is crucial for preventing $\mathrm{T}$ cell auto-reactivity; however, tumor cells have co-opted these pathways to subvert cytolysis by host T cells. Indeed, studies suggest over $50 \%$ of primary PCa express moderate to high levels of PD-L1, which is associated with reduced biochemical recurrence-free survival after radical prostatectomy [88]. The efficacy of PD-1 and PD-L1 blocking antibodies to relieve this suppression and reinvigorate anti-tumor immune responses in PCa remains unclear, although one recent clinical trial suggests it may be beneficial for a subset of patients [89].

\subsection{Cell-Mediated Immunosuppression}

Several tumor-associated immune cell subsets have been identified as key players facilitating immunosuppression and tumor progression in $\mathrm{PCa}$, including $\mathrm{T}$ regs, myeloid-derived suppressor cells (MDSC), tumor-associated macrophages (TAMs), and select $B$ cell subsets. $T$ regs are best described phenotypically as CD4+CD25+FoxP3+ T cells. This TIL subset has a classical role in mediating protection from autoimmunity and promoting tolerance via several immunosuppressive mechanisms [90]. It is, therefore, not surprising that $\mathrm{T}$ regs are enriched in both the tumor and peripheral blood of PCa patients [82,91]. Prostate tumors may also recruit MDSC, a heterogeneous population of immature myeloid cells and myeloid precursors. These cells actively suppress $\mathrm{T}$ cell responses within the tumor, and increased frequencies of circulatory MDSC in PCa patients has been shown to correlate with negative prognostic indicators, including elevated PSA levels and reduced overall survival [91]. Mononuclear MDSC can also differentiate into TAMs. Tissue resident macrophages adopt a spectrum of phenotypically diverse activation states in response to the different signalling cues within the tissue microenvironment. These activation states either support inflammation (M1-like), or suppress adaptive immune responses and promote tissue repair during the resolution of an immune response (M2-like) [92]. Within prostate tumors, TAMs are more commonly polarized toward a M2-like phenotype and promote angiogenesis, progression, and metastasis $[92,93]$. Not surprisingly, TAM infiltration has been shown to correlate with several clinicopathologic indicators including serum PSA, Gleason score and clinical T stage [94]. Finally, there is emerging evidence highlighting a role for B cells in the inhibition of anti-tumor CTL responses in PCa. A recent report identified a class of immunosuppressive tumor-infiltrating $\operatorname{IgA}+$ plasmocytes in both human and murine PCa [95]. These cells expressed IL-10 and PD-L1, and mediated resistance to immunogenic chemotherapy by suppressing anti-tumor CTL. In addition, B cell-derived lymphotoxin was shown to be important for the development of castration-resistant disease in the Transgenic Adenocarcimoa of the Mouse Prostate (TRAMP) model of PCa [96]. This information is unexpected given the association between tumor-infiltrating B cells and favorable prognosis in other settings such as ovarian cancer [97].

\subsection{Suppression of Antigen Presentation and T Cell Priming}

Prostate tumors may also interfere with the earliest stages of $\mathrm{T}$ cell activation by causing priming of suboptimal $\mathrm{T}$ helper $2\left(\mathrm{~T}_{\mathrm{H}} 2\right)$ or $\mathrm{T}$ helper $17\left(\mathrm{~T}_{\mathrm{H}} 17\right)$-type immune responses. Secretion of soluble mediators by prostate tumors (e.g., TGF $\beta$ IL-10, IL-6, COX-2, iNOS) interfere with dendritic cell (DC) maturation in a manner that inhibits strong $\mathrm{T}_{\mathrm{H}}$ 1-type immune responses and can lead to induction of antigen-specific $\mathrm{T}$ cell anergy and outgrowth of $\mathrm{T}$ regs. In addition, tumor-derived soluble mediators (e.g., IL-10, COX-1/2, VEGF, GM-CSF, IL-1 $\beta$ ) can alter DC differentiation to preclude development of cells with antigen-presentation function and instead skew differentiation of DC precursors into immunosuppressive TAMs and MDSC [98,99]. Lastly, PCa possess an additional unique mode of immunosuppression mediated by secretory PSA, which has been shown to inhibit generation and maturation of DC in vitro and suppress their ability to induce T cell proliferation [100].

Overall, prostate tumors create multiple barriers to achieving a successful, active, anti-tumor adaptive immune response. These features provide a unique opportunity to use immunotherapy as a means to overcome these negative regulatory networks in PCa. 


\section{The Role of ADT in Modulation of Immune Responses}

Due to the inherent dependency of prostate tumors on the AR, the primary anti-tumor effect of ADT is a result of directly inducing tumor cell apoptosis. However, emerging evidence suggests that ADT may also indirectly lead to the priming of tumor-specific adaptive immune responses [101]. Although ADT may elicit these dual benefits on both the tumor and the immune system, patients treated with ADT, particularly those with more disease burden, often experience biochemical relapse. As discussed below, if ADT initially supports anti-tumor $\mathrm{T}_{\mathrm{H}}$ 1-type responses, these are likely short-lived and eventually an immunosuppressive TIL landscape predominates. In these cases, it may be beneficial to provide additional stimuli, such as RT or immunotherapy, to promote skewing towards more favourable and durable anti-tumor immune responses.

New data has highlighted the importance of AR signalling in immune regulation. For example, conditional knockout of the AR in B and T cells improves lymphocyte development and activation, while castration causes thymic enlargement and increased levels of peripheral immature B cells and naive $\mathrm{T}$ cells [102]. This implies that androgens have a negative regulatory effect on lymphocyte development and activity. Indeed, androgens have been shown to directly inhibit $\mathrm{T}_{\mathrm{H}} 1$ differentiation [68]. Alternatively, there may also be a prostate-dependent effect on TIL after ADT. As demonstrated in animal models, castration is able to mitigate tolerance to prostate antigens and cause an influx of prostate-infiltrating lymphocytes that are, at least transiently, $\mathrm{T}_{\mathrm{H}} 1$-biased $[103,104]$. Therefore, it appears that the androgen-AR axis can have a profound suppressive effect on the behaviour of various lymphocyte subsets. It is not surprising, then, that ADT has a positive influence on anti-tumor immune responses; however, it prompts to question why PCa patients treated with standard ADT fail to develop effective immune responses and eventually experience tumor relapse. In one clinical report, ADT promoted strong adaptive anti-tumor $\mathrm{T}$ and $\mathrm{B}$ cell responses; however, peripheral $\mathrm{T}_{\mathrm{H}} 1$ and $\mathrm{T}_{\mathrm{H}} 17$ effector memory subsets were diminished after two years of therapy [101]. Thus, it appears that these beneficial responses may be short-lived, or even blunted, by concomitant changes in other lymphocyte subsets. For instance, castration was shown to cause induction of strong anti-tumor $\mathrm{CD} 8+\mathrm{T}$ cell responses but these changes were accompanied by a concomitant increase in CD4+CD25+FoxP3+ T regs [105]. A similar report by Sorrentino et al. [78] showed that patients treated with hormone therapy prior to radical prostatectomy had increased levels of TIL with both cytotoxic and regulatory $\mathrm{T}$ cell phenotypes. Furthermore, it was recently shown that ADT stimulates tumor cells to produce macrophage colony stimulating factor-1 (M-CSF1), leading to increased TAM infiltrates in both PCa patients and tumor-bearing mice [106]. Finally, new evidence shows that the type of ADT can be a determining factor in how adaptive immune responses change following androgen ablation. In a recent preclinical report by $\mathrm{Pu}$ et al. [107], the authors conducted a direct comparison between surgical androgen depletion, a LHRH-analogue, and an AR antagonist (flutamide). First, neither surgical nor LHRH-analogue ADT resulted in inhibitory effects on T cell responses. In contrast, flutamide interfered with initial T cell priming, impaired efficacy of anti-PD-L1 therapy, and led to earlier tumor relapse. Thus, it appears that the specific mode of androgen suppression has important implications for downstream immunological effects. Whether more advanced AR blocking agents (e.g., enzalutamide and abiraterone) share these immunosuppressive properties is a critical question that needs to be resolved. Next, we discuss the concepts related to RT-induced immune activation and how RT, in combination with ADT, may be beneficial for anti-tumor immunity.

\section{How RT Improves Tumor Immunogenicity}

\subsection{RT Promotes Immunogenic Cell Death and Antigen Presentation}

Tumor cell death is a prime source of antigens for uptake by DC. Indeed, a secondary response to $\mathrm{RT}$ is the release of endogenous tumor antigens via apoptotic or necrotic cell death, which are captured by $\mathrm{DC}$, processed, and presented to CD4+ and CD8+ T cells. A large body of preclinical evidence and several clinical case reports support the notion that RT can favor anti-tumor immune activation. 
First, RT has been shown to increase tumor MHC class I expression in a dose-dependent manner both in vitro and in vivo [108]. RT also causes release of danger-associated molecular patterns (DAMPs) from stressed or dying tumor cells, including pro-inflammatory cytokines (e.g., TNF $\alpha$, IFN $\gamma, \operatorname{IL}-1 \alpha / \beta$ ) and other immune-stimulatory factors (e.g., ATP, HMGB1, cyclic dinucleotide, calreticulin) in what has been described as 'immunogenic cell death' [109-111]. For these reasons, RT is thought to act as an "in situ tumor cell vaccine", whereby CD4+ and CD8+ T cell responses are generated through antigen release and acquisition by DC in the presence of the appropriate stimuli.

\subsection{RT Disrupts the Balance Between Pro-Inflammatory and Immunosuppressive Soluble Factors}

Numerous studies have demonstrated that RT leads to increased local production of soluble factors that promote anti-tumor immunity by enhancing activation of local innate immune cells and recruitment of tumor-reactive T cells (e.g., CXCL16, IL-1 $\alpha / \beta$, IFN $\gamma$, and TNF $\alpha$ ) $[109,112,113]$. Paradoxically, these factors may also play a role in tumor progression. For example, IL- $1 \alpha$ and IL- $1 \beta$ promote angiogenesis and invasiveness in some cancer models [114], and other studies have found a link between elevated plasma levels of TNF and negative clinical outcomes [115]. It should be pointed out that RT has purported roles in immune suppression, including RT-induced production of tumor M-CSF1. In principle, this may increase the levels of circulating MDSC [116], adding complexity to how RT can alter the immune response in PCa. Furthermore, RT has been shown to promote activation of TGF- $\beta 1$. This cytokine, while classically known for its immunoregulatory properties [117], induces CD103 expression on activated T cells, which facilitates tumor infiltration and recognition. Indeed CD103+ TIL are associated with favorable prognosis in some settings [118-120]. Whether RT leads to increased CD103+ TIL in PCa is not yet known; however, these data show that RT-induced production of soluble factors can have both complementary and opposing effects which may have implications for subsequent immune modulation.

\section{Can ADT and RT Synergize with Immunotherapy?}

ADT and RT can independently enhance tumor immunity by modulating both local and systemic molecular and cellular responses (summarized in Figure 1). If this combination is superior to either treatment alone, why then do we not observe more exceptional outcomes in patients treated with these modalities? In fact, a large proportion of patients treated with ADT and RT eventually progress to castration-resistant disease. While there are many possible reasons for this, we speculate that both the class of ADT and the sensitivity of tumors to radiation are crucial parameters that determine clinical responses. Furthermore, given the dual nature of some of the effects of ADT and RT discussed above, the temporal sequence of these treatments relative to each other could have either synergistic or antagonistic consequences on local and systemic immune responses. Therefore, any attempts to elicit robust responses with immune modulatory agents must take careful consideration of the treatment scheme (i.e., type, dose, duration, and timing). Another concern is when peak tumor cell death and release of "immune signals" (e.g., DAMPs, tumor antigens) occurs as a result of ADT or RT, as these are transient processes that need to be precisely timed with immune modulation. Given what we know, one simple way to think about combinational treatment is that ADT and RT may prime anti-tumor $\mathrm{T}$ cell responses but full conversion to effector activity may require additional immunotherapeutic intervention. 

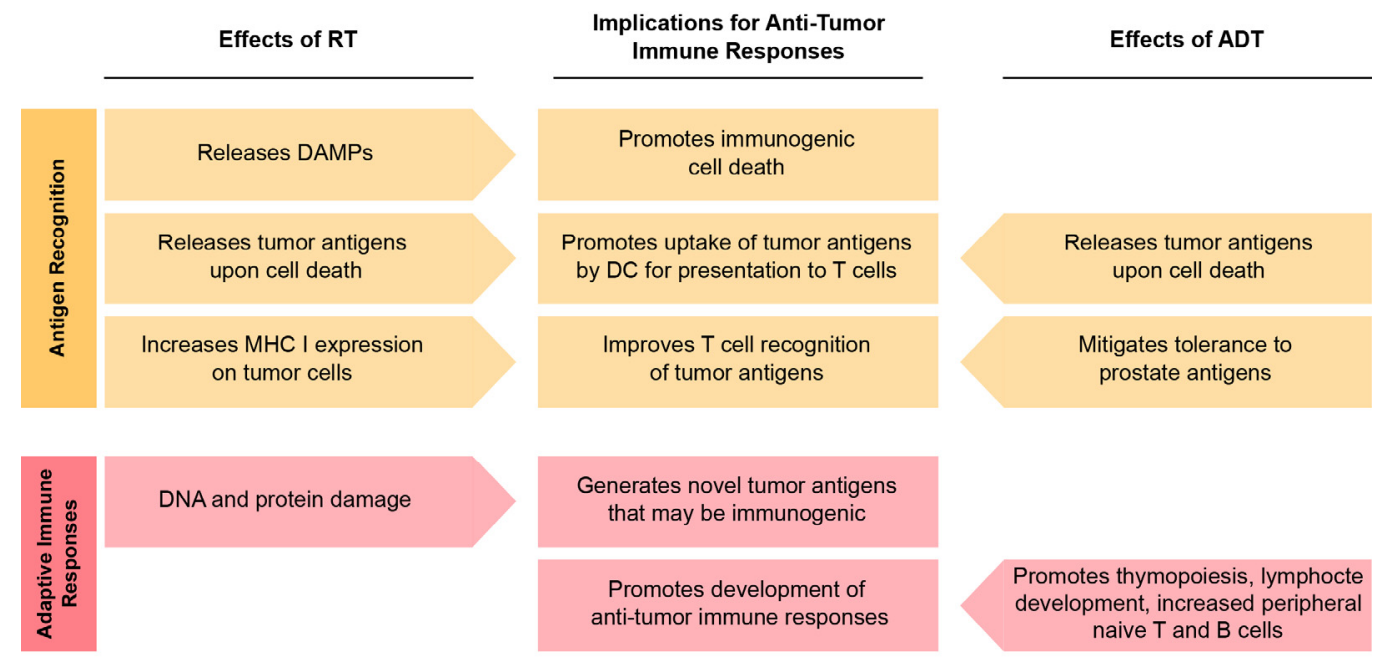

Promotes thymopoiesis, lymphocte development, increased peripheral naive $T$ and $B$ cells
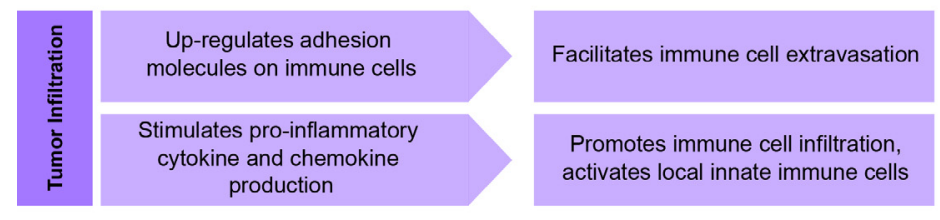

Promotes tumor immune cell infiltration
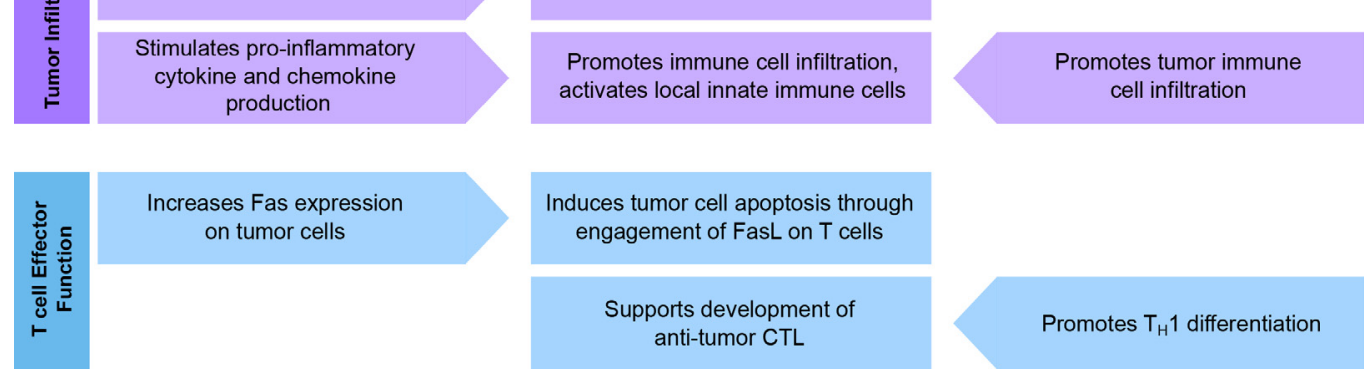

Figure 1. Cellular and molecular effects of ADT and RT as they relate to the development of anti-tumor immunity.

Preclinical studies have demonstrated that castration may augment vaccine-induced immune responses [121]. A notable case report of a patient with MCRPC who achieved a complete and durable PSA decline after treatment with ADT and sipuleucel-T highlights the potential for combination strategies in advanced human PCa [122]. This patient, having progressed on enzalutamide and LHRH-agonist therapy, received sipuleucel-T and six months later experienced a drastic PSA decline that remained undetectable thereafter. The authors point out that such drastic PSA reductions after sipuleucel-T are rare, and the delayed onset of the response implies an immune-mediated mechanism. Furthermore, anecdotal reports of patients experiencing reductions in untreated metastases after receiving RT to a single lesion, a phenomenon known as the abscopal response, are believed to be systemic anti-tumor immune responses triggered by RT [123-128]. Several case reports of abscopal responses in patients treated with RT and immunotherapy suggest that the paucity of this phenomenon might be improved by combination strategies [128-130]. Indeed, this has been repeatedly observed in pre-clinical models [131-134] and affirmed by a small retrospective cohort study of sequential checkpoint blockade (ipilimumab) and RT in melanoma, where abscopal responses were observed in $52 \%$ of patients analysed $(n=21)$ and were correlated with improvements in overall survival [130]. To date, there have been no known accounts of abscopal responses in metastatic PCa; however, there is some clinical evidence of induction of anti-tumor immune responses after RT. Nesslinger et al. [135] found that $14 \%$ of patients who received EBRT and $25 \%$ of those treated with brachytherapy developed tumor-specific antibody responses, while none were detected in patients who underwent radical prostatectomy. In addition, two new reports suggest a survival benefit for patients with metastatic disease treated with ADT and prostate RT $[38,136]$. This emerging evidence in favor of local therapy in 
the metastatic setting has led to the initiation of several clinical trials [137-139], providing a possible opportunity to evaluate abscopal responses in metastatic PCa.

\section{Current Status of Early Clinical Trials of Immunotherapy in Combination with ADT and RT}

Clinical trials with several different classes of immune modulators are now being intensely pursued in PCa. In 2010, the FDA approved the use of sipuleucel-T (Provenge ${ }^{\circledR}$, Dendreon, Seattle, WA, USA) as the first therapeutic vaccine for minimally symptomatic mCRPC. Several trials have tested ipilimumab (Yervoy ${ }^{\mathrm{TM}}$, Bristol-Myers Squibb, New York, NY, USA) and more recently, ongoing trials with pembrolizumab (KEYTRUDA ${ }^{\circledR}$, Merck Sharp \& Dohme Corp., Kenilworth, NJ, USA) and nivolumab (Opdivo ${ }^{\circledR}$, Bristol-Myers Squibb, New York, NY, USA) as checkpoint blockade immunotherapy in PCa. While these advances have been encouraging, in many cases immune modulation alone fails to provide superior improvements in survival compared to conventional anti-cancer therapies [140,141]. Thus, it appears that the many barriers to achieving anti-tumor immunity continue to hinder the success of current immunotherapies and more effective alternatives are clearly needed. Here, we summarize the findings of early clinical trials evaluating ADT and RT in combination with different immunotherapy modalities, with the presumption that the direct cytotoxic and immune-stimulating properties of ADT and RT outlined above may synergize with immunotherapy and augment the efficacy of either modality on its own. One key consideration is that the majority of clinical trials for advanced PCa employ ADT as the standard of care, and were not designed to evaluate the effect that ADT may have on clinical or immunological outcomes. However, there is an appreciation that ADT can alter the course of immune responses and new trials are being planned with this consideration in mind. Importantly, the class of ADT will likely be crucial, but this question has not yet been evaluated. In the studies discussed here, some of the details regarding ADT are not made available, although most patients remain on continuous androgen suppressive therapy for the duration of the trial unless specifically stated otherwise. A complete list of the current and ongoing clinical trials combining ADT, RT, and immunotherapy in PCa are provided in Table 1.

\subsection{Vaccines}

Therapeutic vaccination against tumor associated antigens (TAA) has been explored as a means to promote DC activation and antigen presentation to $\mathrm{T}$ cells in cases where there may be a lack of available antigens or necessary maturation signals. Cancer vaccines come in many forms, including, but not limited, to direct DNA, mRNA, or peptide injection, injection of autologous TAA-expressing DC, or DC co-cultured with tumor cell lysates, and injection of TAA- or cytokine-expressing recombinant viral vectors. This section will focus on select vaccine trials involving both ADT and RT.

The first approved immunotherapy for $\mathrm{PCa}$, sipuleucel-T, involves infusion of a patient's autologous DC that have been pre-loaded with a recombinant fusion protein consisting of a known prostate TAA, prostatic acid phosphatase (PAP), fused with granulocyte-macrophage colony-stimulating factor (GM-CSF). In the original phase III trial, sipuleucel-T imparted a moderate improvement in overall survival compared to the placebo (25.8 months vs. 21.7 months) [140]. This modest, but encouraging finding has prompted strategies of sipuleucel-T with ADT and RT, and the results of several ongoing clinical trials are pending [142-145]. In a pilot study of intraprostatic DC injection, patients initiated fractionated EBRT while remaining on androgen-suppressive therapy (GnRH-agonist and bicalutamide) [146]. Autologous DC were injected following fractions 5, 15, and 25 of EBRT, allowing approximately $72 \mathrm{~h}$ before the next radiation dose. After 25 fractions ( $45 \mathrm{~Gy}$ total), patients proceeded to brachytherapy. Two patients had induction of prostate antigen-specific $\mathrm{T}$ cell responses after the initiation of treatment. Conversely, one patient had pre-existing $\mathrm{T}$ cell responses to PSA, PSMA, and Her2/neu that were diminished at later time points. Although this treatment approach was determined feasible, the small sample size $(n=5)$ precluded conclusions regarding clinical benefit. Larger studies are needed to further uncover the optimal coordination of DC-based immunotherapy with the peak of RT-induced tumor apoptosis and inflammatory responses. 
The use of three co-stimulatory molecules (B7.1, ICAM-1, and LFA-3) in a carcinoembryonic antigen (CEA) recombinant viral vaccine (called TRICOM) was shown to enhance $T$ cell proliferation and confer an overall survival advantage in CEA+ tumor-bearing mice compared to vaccination with only one or none of these molecules [147]. Based on these findings, several phase I and II clinical trials have been launched using recombinant viral and TRICOM-based vaccines targeting PSA, CEA, and mucin-1 (MUC-1) in various cancer settings [148-152]. Currently, a handful of proof-of-concept studies have been completed that assessed safety recombinant viral-B7.1- or TRICOM-based vaccines against PSA in conjunction with standard ADT and RT in PCa [153-155]. A randomized phase II trial found that patients treated with PSA-TRICOM and ${ }^{135} \mathrm{Sm}$-EDTMP had increased levels of PSA-specific T cells and lower levels of circulating MDSC subsets compared to patients in the ${ }^{135} \mathrm{Sm}$-EDTMP alone arm at 60 days post-therapy [155]. In this same study, $>30 \%$ PSA declines were only observed in the vaccine arm. While no statistical difference in overall survival was observed, patients receiving ${ }^{135} \mathrm{Sm}$-EDTMP and PSA-TRICOM had progression-free survival (PFS) more than twice that of those receiving ${ }^{135} \mathrm{Sm}$-EDTMP alone ( 3.7 months vs. 1.7 months, respectively).

In another phase II study, standard EBRT and ADT were combined with a similar vaccine strategy against PSA using rV-B7.1, IL-2 and GM-CSF [153]. Here, 13/17 patients treated with RT plus the vaccine regimen had at least three-fold increases in circulating PSA-specific $T$ cells post-vaccination, while patients in the RT alone control arm had no detectable increase in such $\mathrm{T}$ cells $(p<0.0005)$ [153]. In two of the responding patients, the increase in PSA-specific T cells was observed following completion of RT, suggesting that RT enhanced immune responses to PSA in some cases. Conversely, eight patients had increases in PSA-specific T cells post-vaccination that then decreased following RT; however, these levels recovered with subsequent vaccine boosts in four patients. This study also noted evidence of epitope spreading in $6 / 8$ patients evaluated, as indicated by the appearance of new responses to other known PCa associated antigens (PMSA, PAP, PSCA, and MUC-1) after vaccination but before the initiation of RT. Finally, while there was no significant difference in PSA-specific $\mathrm{T}$ cell responses between patients in the vaccine arm who did or did not receive $\mathrm{ADT}(3 / 17)$, there were too few patients to draw any conclusions regarding the immunological effects of ADT in this setting.

These early data suggest that ADT and RT in combination with recombinant viral vaccines is feasible, although it is not clear to what extent RT contributes to, or antagonizes, anti-tumor immunity induced by vaccination in these studies. In the case of the latter, it appears it may be possible to recover any immunosuppressive effects of RT with subsequent immune modulation.

\subsection{Checkpoint Blockade}

Checkpoint blockade immunotherapies have contributed to one of the most significant improvements in cancer therapeutics to date. Currently, three indications have been approved by the FDA for treating melanoma, NSCLC, and renal cell carcinoma: ipilimumab, pembrolizumab, and nivolumab. In general terms, this class of immune modulators comprises antibodies that block the interactions between the $\mathrm{B} 7 \mathrm{H}$ receptor-ligand family of surface co-stimulatory molecules. In either case, these agents alleviate $\mathrm{T}$ cell suppression during activation and effector stages. There are two general classes of approved checkpoint blockade inhibitors: those that target CTLA-4, and those that target the PD-1/PD-L1/L2 pathway. The principal idea behind checkpoint blockade in combination with RT is that tumor cell killing by RT acts as an in situ vaccine that can help release TAA and pro-inflammatory factors that promote priming of systemic anti-tumor $\mathrm{T}$ cell responses. These responses are then enhanced by checkpoint blockade, which minimizes ongoing suppression from $\mathrm{T}$ cell engagement with tumors and surrounding suppressor cells. This concept has been successfully demonstrated in numerous preclinical tumor models but here we will focus on human trials that have attempted to recapitulate these results.

A randomized, double-blind phase III clinical trial comparing ipilimumab monotherapy ( $n=399)$ to placebo $(n=400)$ in mCRPC patients having undergone a single fraction of RT (8 Gy) and prior 
docetaxel did not reach statistical significance with its primary endpoint of overall survival, but found that ipilimumab was associated with reductions in PSA and slight improvements in PFS (median 4.0 months vs. 3.1 months PFS) [156]. Despite this study not meeting its primary endpoint, the authors suggest that these signs of anti-tumor activity warrant further investigation of ipilimumab in PCa, especially amongst a less advanced population that have not received prior chemotherapy.

Immunotherapy targeting the PD-1 axis is seeing unprecedented responses, particularly in the settings of melanoma and NSCLC [157-160]. Notably, patients treated with pembrolizumab or nivolumab have significant improvements in overall survival and PFS, and experience reduced toxic side effects compared to treatment with ipilumumab or other standard chemotherapy regimens [157-161]. Currently, several clinical trials of PD-1 blockade are ongoing in the PCa setting [162-164]. Early results from a phase II trial involving pembrolizumab in combination with enzalutamide reported complete PSA responses in 3/10 patients, two of which also experienced partial tumor reductions [89]. This latest report supports the continued examination of PD-1 blockade in PCa. Clinical trials evaluating safety and efficacy of anti-PD-1 immunotherapy in combination with ADT and RT are not yet underway.

\section{Synchronization of Immunotherapy with ADT and RT}

\subsection{RT Dose and Fractionation}

The ability of RT to induce an anti-tumor immune response depends on both the dose and fractionation scheme as well as the inherent properties of the tumor itself $[165,166]$. To date, the absolute dose required to elicit immune effects in a clinical setting is undefined and likely patient-dependent, although some evidence suggests the relative immunogenicity of a tumor positively correlates with increasing dose of radiation [108,112]. On the contrary, one study demonstrated that while increasing doses of single fraction RT correlated with increased tumor-reactive T cells, higher doses (e.g., $15 \mathrm{~Gy}$ ) offset immune responses due to an elevation in T reg populations [166]. As a result, a more moderate dose (7.5 Gy) offered the most effective tumor control by instigating anti-tumor $\mathrm{T}$ cell responses while avoiding concomitant increases in $\mathrm{T}$ regs. In addition, one must consider how single-dose versus fractionated RT schemes affect immune modulation. Fractionation is routinely employed to permit recovery of normal tissue between treatments while targeting tumor cells during the most sensitive phases of the cell cycle. While single or hypofractionated high-dose RT schemes have been suggested to provide superior immune-mediated tumor control $[167,168]$, using a fractionated scheme may help sustain pro-inflammatory cytokine production, thus opening a larger window of opportunity for synergy with immunotherapy [109]. For instance, one study demonstrated that fractionated $(3 \times 8 \mathrm{~Gy}$ and $5 \times 6$ Gy), but not single-dose (20 Gy) RT induced abscopal responses when combined with CTLA-4 blockade in a breast cancer model [133]. 
Table 1. Current clinical trials involving immunotherapy in combination with ADT and RT in PCa (completed and in-progress).

\begin{tabular}{|c|c|c|c|c|c|}
\hline ClinicalTrials.Gov Identifier & Phase & Immunotherapy & ADT & RT & Timing \\
\hline NCT02107430 [169] & 2 & $\mathrm{DCVAC} / \mathrm{PCa}$ & LHRH-a & Standard EBRT & DCVAC/PCa after RP and RT; Neo-adjuvant LHRH-a \\
\hline PMC4241355 [146] & 0 & $\begin{array}{l}\text { Dendritic Cell } \\
\text { Vaccine }\end{array}$ & GnRH-a and Bicalutamide & $\begin{array}{l}\text { EBRT ( } 45 \text { Gy in } 25 \\
\text { fractions) and BT }\end{array}$ & $\begin{array}{l}\text { ADT start 30-44 days before RT; intraprostatic DC injection } \\
\text { after fractions } 5,15 \text {, and } 25\end{array}$ \\
\hline NCT00323882 [170] & 1,2 & Ipilimumab & $\begin{array}{l}\text { Prior disease progression } \\
\mathrm{w} / \mathrm{ADT}\end{array}$ & EBRT (8 Gy/lesion) & $\begin{array}{l}\text { Prior ADT; Single dose RT to bone metastases }<2 \text { days } \\
\text { before Ipilimumab }\end{array}$ \\
\hline NCT00861614 [171] & 3 & Ipilimumab & Prior ADT & EBRT (8 Gy/lesion) & $\begin{array}{l}\text { Prior ADT; Single dose RT to bone metastases }<2 \text { days } \\
\text { before Ipilimumab or placebo }\end{array}$ \\
\hline NCT01777802 [172] & 0 & $\begin{array}{l}\text { Monitor Timing for } \\
\text { Immune Modulation }\end{array}$ & Prior ADT & SBRT & Monitor for immune changes after RT \\
\hline NCT01436968 [173] & 3 & ProstAtak ${ }^{\mathrm{TM}}(\mathrm{AdV}$-tk) & 6 months ADT & Standard EBRT & $\begin{array}{l}\text { Two doses of ProstAtak }{ }^{\mathrm{TM}}(\mathrm{AdV}-\mathrm{tk}) \text { or placebo before RT, } \\
\text { 3ird dose during RT; short term (6mo) ADT optional }\end{array}$ \\
\hline NCT00005916 [174] & 2 & $\begin{array}{l}\text { rV-PSA, rV-B7.1, } \\
\text { GM-CSF and IL-2 }\end{array}$ & Ongoing ADT allowed & Standard EBRT +/ - BT & $\begin{array}{l}\text { GM-CSF on days 1-4, rV-PSA/rV-B7.1 on day 2, low dose IL-2 } \\
\text { on days 8-21 (repeat cycle every } 28 \text { days); RT after 3rd cycle }\end{array}$ \\
\hline NCT00005916 [174] & 2 & $\begin{array}{l}\text { rV-PSA, rV-B7.1, } \\
\text { GM-CSF and IL-2 }\end{array}$ & Ongoing ADT allowed & Standard EBRT + / - BT & $\begin{array}{l}\text { GM-CSF on days } 1-4 \text {, rV-PSA /rV-B7.1 on day } 2 \text {, IL- } 2 \text { on days } \\
8-12 \text { (repeat cycle every } 28 \text { days); RT between } 4 \text { th and } 6 \text { th cycle } \\
\text { PROSTVAC-TRICOM on dav } 1.15 .29 \text { and every } 28 \text { davs }\end{array}$ \\
\hline NCT00450619 [175] & 2 & PROSTVAC-TRICOM & Ongoing ADT & ${ }^{153}$ Sm-EDTMP & $\begin{array}{l}\text { thereafter; }{ }^{153} \text { Sm-EDTMP starting on day } 8 \text { and } \\
\text { every } 12 \text { weeks thereafter }\end{array}$ \\
\hline NCT01807065 [142] & 2 & Sipuleucel-T & $\begin{array}{l}\text { Disease progression } \\
\mathrm{w} / \mathrm{ADT}\end{array}$ & EBRT & $\begin{array}{l}\text { RT in weeks } 1-2 \text { to a single metastasis, } \\
\text { Sipuleucel-T on days } 22,36 \text {, and } 50\end{array}$ \\
\hline NCT01818986 [143] & 2 & Sipuleucel-T & Ongoing ADT & SABR & Not specified \\
\hline NCT02463799 [144] & 2 & Sipuleucel-T & $\begin{array}{l}\text { Disease progression } \\
\mathrm{w} / \mathrm{ADT}\end{array}$ & ${ }^{223} \mathrm{Ra}$ & $\begin{array}{l}{ }^{223} \text { Ra every } 4 \text { weeks ( } 6 \text { cycles); Sipuleucel-T every } 2 \text { weeks } \\
\text { starting on week } 6 \text { ( } 3 \text { cycles) }\end{array}$ \\
\hline NCT02232230 [145] & 2 & Sipuleucel-T & Prior ADT & EBRT & RT to metastases 28 days prior to Sipuleucel-T \\
\hline NCT01496131 [176] & 2 & $\begin{array}{l}\text { Tecemotide } \\
\text { (L-BLP25) }\end{array}$ & Goserelin & $\begin{array}{l}\text { EBRT ( } 54-72 \text { Gy in } \\
30-40 \text { fractions) }\end{array}$ & Tecemotide and ADT start $2-3$ months before starting RT \\
\hline
\end{tabular}

Abbreviations: luteinizing-hormone-releasing hormone analogues (LHRH-a); gonadotropin-releasing hormone agonist (GnRH-a); samarium-153-ethylenediamine tetramethylene phosphonic acid $\left({ }^{153} \mathrm{Sm}-\mathrm{EDTMP}\right)$; radium-223 $\left({ }^{223} \mathrm{Ra}\right)$; recombinant Vaccinia $(\mathrm{rV})$; prostate-specific antigen (PSA); stereotactic ablative radiotherapy (SABR); Interleukin-2 (IL-2); granulocyte macrophage colony stimulating factor (GM-CSF); external beam radiation therapy (EBRT); brachytherapy (BT); stereotactic body radiation therapy (SBRT); radical prostatectomy (RP). 


\subsection{Timing}

In general, RT promotes $\mathrm{T}$ cell priming through the release of tumor antigens and pro-inflammatory soluble mediators while ADT promotes lymphopoiesis, immune cell trafficking and tumor infiltration. Both strategies can be used in combination with immunotherapy to enhance these processes. Thus, maximum synergy may be achieved by precisely timing each intervention during the appropriate phase of a therapy-induced immune response. However, the timing of immune modulation is not straightforward and depends on many factors, such as the type of ADT, the RT strategy (i.e., type, dose, duration), and the immunotherapeutic agent being administered. For instance, in an animal model of colorectal cancer, anti-CTLA-4 immunotherapy was most effective when given prior to RT, while an OX40 agonist antibody was optimal when delivered one day after RT [177]. In another study, anti-PD-1 was only effective if administered concurrently, but not following fractionated RT [178]. On the other hand, it may be ideal to deliver intratumoral DC between fractionated RT cycles, taking into account the effects of RT on DC and their migration to tumor-draining lymph nodes $[146,179]$. The timing of immune modulation is further complicated by the tumor's inherent susceptibility to ADT and RT. Indeed, radioresistance and androgen independence are characteristic of PCa $[180,181]$. One may need to consider a personalized approach first by identifying susceptible characteristics of an individual tumor, and second by devising an appropriate strategy that considers therapy synchronization. No doubt, there is clear evidence demonstrating the importance of coordinated therapy $[177,178,182]$ and this concept is gaining recognition in the clinical setting $[146,153]$. However, there has yet to be developed standardized definitions and assays for quantitative clinical evaluation of therapy-induced immunologic effects. With this question in mind, new approaches to identify signatures of immunogenic cell death and model $\mathrm{T}$ cell trafficking are under development $[137,183,184]$.

\section{Concluding Remarks}

ADT is not immunologically inert; however, many trials were not historically designed to consider the potential effects of ADT on subsequent immune modulation. In many cases ADT is administered at the discretion of the treating physician, however further published details (e.g., type and timing) are scarce. As we move into an era of cancer immunotherapy, the effects of ADT on the immune system and its impact on the success of emerging immunotherapies in PCa will require careful scrutiny in future trial designs. This is especially important in light of new information that certain classes of ADT may actually have negative immunological consequences [107]. Nonetheless, experience thus far, both in animal models and in the clinic, highlights the promise of ADT, RT and immunotherapy as a combination strategy, a prospect that awaits the results of upcoming phase III trials.

Acknowledgments: We are grateful for funding from the Prostate Cancer Canada Discovery Grant (Julian J. Lum), WestCoast Ride to Live (Julian J. Lum, Joanna Vergidis, Abraham S. Alexander) and the Prostate Cancer Fight Foundation (Julian J. Lum). The funds cover personnel salaries and research consumable costs but not open access fees for publication.

Conflicts of Interest: The authors declare no conflict of interest.

\section{References}

1. Huggins, C. Effect of Orchiectomy and Irradiation on Cancer of the Prostate. Ann. Surg. 1942, 115, 1192-1200. [CrossRef] [PubMed]

2. Bolla, M.; Van Tienhoven, G.; Warde, P.; Dubois, J.B.; Mirimanoff, R.O.; Storme, G.; Bernier, J.; Kuten, A.; Sternberg, C.; Billiet, I.; et al. External irradiation with or without long-term androgen suppression for prostate cancer with high metastatic risk: 10-Year results of an EORTC randomised study. Lancet Oncol. 2010, 11, 1066-1073. [CrossRef] 
3. D'Amico, A.V.; Whittington, R.; Malkowicz, S.B.; Schultz, D.; Blank, K.; Broderick, G.A.; Tomaszewski, J.E.; Renshaw, A.A.; Kaplan, I.; Beard, C.J.; et al. Biochemical outcome after radical prostatectomy, external beam radiation therapy, or interstitial radiation therapy for clinically localized prostate cancer. JAMA 1998, 280, 969-974. [CrossRef] [PubMed]

4. D'Amico, A.V.; Whittington, R.; Malkowicz, S.B.; Schultz, D.; Renshaw, A.A.; Tomaszewski, J.E.; Richie, J.P.; Wein, A. Optimizing patient selection for dose escalation techniques using the prostate-specific antigen level, biopsy gleason score, and clinical T-stage. Int. J. Radiat. Oncol. Biol. Phys. 1999, 45, 1227-1233. [CrossRef]

5. Hernandez, D.J.; Nielsen, M.E.; Han, M.; Partin, A.W. Contemporary evaluation of the D'amico risk classification of prostate cancer. Urology 2007, 70, 931-935. [CrossRef] [PubMed]

6. Wilt, T.J.; Brawer, M.K.; Jones, K.M.; Barry, M.J.; Aronson, W.J.; Fox, S.; Gingrich, J.R.; Wei, J.T.; Gilhooly, P.; Grob, B.M.; et al. Radical prostatectomy versus observation for localized prostate cancer. N. Engl. J. Med. 2012, 367, 203-213. [CrossRef] [PubMed]

7. Hamdy, F.C.; Donovan, J.L.; Lane, J.A.; Mason, M.; Metcalfe, C.; Holding, P.; Davis, M.; Peters, T.J.; Turner, E.L.; Martin, R.M.; et al. 10-Year Outcomes after Monitoring, Surgery, or Radiotherapy for Localized Prostate Cancer. N. Engl. J. Med. 2016, 375, 1415-1424. [CrossRef] [PubMed]

8. Albertsen, P.C.; Hanley, J.A.; Fine, J. 20-year outcomes following conservative management of clinically localized prostate cancer. JAMA 2005, 293, 2095-2101. [CrossRef] [PubMed]

9. Bill-Axelson, A.; Holmberg, L.; Ruutu, M.; Garmo, H.; Stark, J.R.; Busch, C.; Nordling, S.; Häggman, M.; Andersson, S.O.; Bratell, S.; et al. Radical prostatectomy versus watchful waiting in early prostate cancer. N. Engl. J. Med. 2011, 364, 1708-1717. [CrossRef] [PubMed]

10. Grimm, P.; Billiet, I.; Bostwick, D.; Dicker, A.P.; Frank, S.; Immerzeel, J.; Keyes, M.; Kupelian, P.; Lee, W.R.; Machtens, S.; et al. Comparative analysis of prostate-specific antigen free survival outcomes for patients with low, intermediate and high risk prostate cancer treatment by radical therapy. Results from the Prostate Cancer Results Study Group. BJU Int. 2012, 109 (Suppl. S1), 22-29. [CrossRef] [PubMed]

11. King, C.R.; Freeman, D.; Kaplan, I.; Fuller, D.; Bolzicco, G.; Collins, S.; Meier, R.; Wang, J.; Kupelian, P.; Steinberg, M.; et al. Stereotactic body radiotherapy for localized prostate cancer: Pooled analysis from a multi-institutional consortium of prospective phase II trials. Radiother. Oncol. 2013, 109, 217-221. [CrossRef] [PubMed]

12. Loblaw, A.; Cheung, P.; D'Alimonte, L.; Deabreu, A.; Mamedov, A.; Zhang, L.; Tang, C.; Quon, H.; Jain, S.; Pang, G.; et al. Prostate stereotactic ablative body radiotherapy using a standard linear accelerator: Toxicity, biochemical, and pathological outcomes. Radiother. Oncol. 2013, 107, 153-158. [CrossRef] [PubMed]

13. Lu, N.Z.; Wardell, S.E.; Burnstein, K.L.; Defranco, D.; Fuller, P.J.; Giguere, V.; Hochberg, R.B.; McKay, L.; Renoir, J.M.; Weigel, N.L.; et al. International Union of Pharmacology. LXV. The pharmacology and classification of the nuclear receptor superfamily: Glucocorticoid, mineralocorticoid, progesterone, and androgen receptors. Pharmacol. Rev. 2006, 58, 782-797. [CrossRef] [PubMed]

14. Tan, M.H.; Li, J.; Xu, H.E.; Melcher, K.; Yong, E.L. Androgen receptor: Structure, role in prostate cancer and drug discovery. Acta Pharmacol. Sin. 2015, 36, 3-23. [CrossRef] [PubMed]

15. Gao, J.; Isaacs, J.T. Development of an androgen receptor-null model for identifying the initiation site for androgen stimulation of proliferation and suppression of programmed (apoptotic) death of PC-82 human prostate cancer cells. Cancer Res. 1998, 58, 3299-3306. [PubMed]

16. Wang, Q.; Carroll, J.S.; Brown, M. Spatial and temporal recruitment of androgen receptor and its coactivators involves chromosomal looping and polymerase tracking. Mol. Cell 2005, 19, 631-642. [CrossRef] [PubMed]

17. Hussain, M.; Tangen, C.M.; Berry, D.L.; Higano, C.S.; Crawford, E.D.; Liu, G.; Wilding, G.; Prescott, S.; Kanaga Sundaram, S.; Small, E.J.; et al. Intermittent versus continuous androgen deprivation in prostate cancer. N. Engl. J. Med. 2013, 368, 1314-1325. [CrossRef]

18. James, N.D.; Sydes, M.R.; Clarke, N.W.; Mason, M.D.; Dearnaley, D.P.; Spears, M.R.; Ritchie, A.W.; Parker, C.C.; Russell, J.M.; Attard, G.; et al. Addition of docetaxel, zoledronic acid, or both to first-line long-term hormone therapy in prostate cancer (STAMPEDE): Survival results from an adaptive, multiarm, multistage, platform randomised controlled trial. Lancet 2016, 387, 1163-1177. [CrossRef]

19. Sweeney, C.J.; Chen, Y.H.; Carducci, M.; Liu, G.; Jarrard, D.F.; Eisenberger, M.; Wong, Y.N.; Hahn, N.; Kohli, M.; Cooney, M.M.; et al. Chemohormonal Therapy in Metastatic Hormone-Sensitive Prostate Cancer. N. Engl. J. Med. 2015, 373, 737-746. [CrossRef] [PubMed] 
20. Messing, E.M.; Manola, J.; Sarodsy, M.; Wilding, G.; Crawford, E.D.; Trump, D. Immediate hormonal therapy compared with observation after radical prostatectomy and pelvic lymphadenectomy in men with node-positive prostate cancer. N. Engl. J. Med. 1999, 341, 1781-1788. [CrossRef] [PubMed]

21. Ryan, C.J.; Smith, M.R.; Fizazi, K.; Saad, F.; Mulders, P.F.; Sternberg, C.N.; Miller, K.; Logothetis, C.J.; Shore, N.D.; Small, E.J.; et al. Abiraterone acetate plus prednisone versus placebo plus prednisone in chemotherapy-naive men with metastatic castration-resistant prostate cancer (COU-AA-302): Final overall survival analysis of a randomised, double-blind, placebo-controlled phase 3 study. Lancet Oncol. 2015, 16, 152-160. [CrossRef]

22. De Bono, J.S.; Logothetis, C.J.; Molina, A.; Fizazi, K.; North, S.; Chu, L.; Chi, K.N.; Jones, R.J.; Goodman, O.B., Jr.; Saad, F.; et al. Abiraterone and increased survival in metastatic prostate cancer. N. Engl. J. Med. 2011, 364, 1995-2005. [CrossRef] [PubMed]

23. Beer, T.M.; Armstrong, A.J.; Rathkopf, D.E.; Loriot, Y.; Sternberg, C.N.; Higano, C.S.; Iversen, P.; Bhattacharya, S.; Carles, J.; Chowdhury, S.; et al. Enzalutamide in metastatic prostate cancer before chemotherapy. N. Engl. J. Med. 2014, 371, 424-433. [CrossRef] [PubMed]

24. Scher, H.I.; Fizazi, K.; Saad, F.; Taplin, M.E.; Sternberg, C.N.; Miller, K.; de Wit, R.; Mulders, P.; Chi, K.N.; Shore, N.D.; et al. Increased survival with enzalutamide in prostate cancer after chemotherapy. N. Engl. J. Med. 2012, 367, 1187-1197. [PubMed]

25. Michalski, J.M.; Yan, Y.; Watkins-Bruner, D.; Bosch, W.R.; Winter, K.; Galvin, J.M.; Bahary, J.P.; Morton, G.C.; Parliament, M.B.; Sandler, H.M. Preliminary toxicity analysis of 3-dimensional conformal radiation therapy versus intensity modulated radiation therapy on the high-dose arm of the Radiation Therapy Oncology Group 0126 prostate cancer trial. Int. J. Radiat. Oncol. Biol. Phys. 2013, 87, 932-938. [CrossRef] [PubMed]

26. Zelefsky, M.J.; Kollmeier, M.; Cox, B.; Fidaleo, A.; Sperling, D.; Pei, X.; Carver, B.; Coleman, J.; Lovelock, M.; Hunt, M. Improved clinical outcomes with high-dose image guided radiotherapy compared with non-IGRT for the treatment of clinically localized prostate cancer. Int. J. Radiat. Oncol. Biol. Phys. 2012, 84, 125-129. [CrossRef] [PubMed]

27. Kok, D.; Gill, S.; Bressel, M.; Byrne, K.; Kron, T.; Fox, C.; Duchesne, G.; Tai, K.H.; Foroudi, F. Late toxicity and biochemical control in 554 prostate cancer patients treated with and without dose escalated image guided radiotherapy. Radiother. Oncol. 2013, 107, 140-146. [CrossRef] [PubMed]

28. Kuban, D.A.; Tucker, S.L.; Dong, L.; Starkschall, G.; Huang, E.H.; Cheung, M.R.; Lee, A.K.; Pollack, A. Long-term results of the M.D. Anderson randomized dose-escalation trial for prostate cancer. Int. J. Radiat. Oncol. Biol. Phys. 2008, 70, 67-74. [CrossRef] [PubMed]

29. Viani, G.A.; Stefano, E.J.; Afonso, S.L. Higher-than-conventional radiation doses in localized prostate cancer treatment: A meta-analysis of randomized, controlled trials. Int. J. Radiat. Oncol. Biol. Phys. 2009, 74, 1405-1418. [CrossRef] [PubMed]

30. Michalski, J.M.; Moughan, J.; Purdy, J.A.; Bosch, W.R.; Bahary, J.; Lau, H.; Duclos, M.; Parliament, M.; Morton, G.; Hamstra, D.A.; et al. Initial Results of a Phase 3 Randomized Study of High Dose 3DCRT/IMRT versus Standard Dose 3D-CRT/IMRT in Patients Treated for Localized Prostate Cancer (RTOG 0126). Int. J. Radiat. Oncol. Biol. Phys. 2014. [CrossRef]

31. Morris, W.J.; Keyes, M.; Spadinger, I.; Kwan, W.; Liu, M.; McKenzie, M.; Pai, H.; Pickles, T.; Tyldesley, S. Population-based 10-year oncologic outcomes after low-dose-rate brachytherapy for low-risk and intermediate-risk prostate cancer. Cancer 2013, 119, 1537-1546. [CrossRef] [PubMed]

32. Johnson, S.B.; Lester-Coll, N.H.; Kelly, J.R.; Yu, J.B.; Nath, S.K. Comparing Overall Survival for Androgen Suppression and Low-Dose-Rate Brachytherapy Boost versus Androgen Suppression and External Beam Radiation Boost for Men with Unfavorable Prostate Cancer. Int. J. Radiat. Oncol. Biol. Phys. 2016. [CrossRef]

33. Morris, W.J.; Tyldesley, S.; Pai, H.; Halperin, R.; McKenzie, M.; Duncan, G.; Morton, G.; Murray, N.; Hamm, J. ASCENDE-RT*: A multicenter, randomized trial of dose-escalated external beam radiation therapy (EBRT-B) versus low-dose-rate brachytherapy (LDR-B) for men with unfavorable-risk localized prostate cancer. J. Clin. Oncol. 2015, 33 (Suppl. S7), abstract 3.

34. Lutz, S.; Berk, L.; Chang, E.; Chow, E.; Hahn, C.; Hoskin, P.; Howell, D.; Konski, A.; Lo, S.; Sahgal, A.; et al. Palliative radiotherapy for bone metastases: An ASTRO evidence-based guideline. Int. J. Radiat. Oncol. Biol. Phys. 2011, 79, 965-976. [CrossRef] [PubMed] 
35. Loblaw, D.A.; Mitera, G.; Ford, M.; Laperriere, N.J. A 2011 updated systematic review and clinical practice guideline for the management of malignant extradural spinal cord compression. Int. J. Radiat. Oncol. Biol. Phys. 2012, 84, 312-317. [CrossRef]

36. Culp, S.H.; Schellhammer, P.F.; Williams, M.B. Might men diagnosed with metastatic prostate cancer benefit from definitive treatment of the primary tumor? A SEER-based study. Eur. Urol. 2014, 65, 1058-1066. [CrossRef] [PubMed]

37. Löppenberg, B.; Dalela, D.; Karabon, P.; Sood, A.; Sammon, J.D.; Meyer, C.P.; Sun, M.; Noldus, J.; Peabody, J.O.; Trinh, Q.D.; et al. The Impact of Local Treatment on Overall Survival in Patients with Metastatic Prostate Cancer on Diagnosis: A National Cancer Data Base Analysis. Eur. Urol. 2016. [CrossRef] [PubMed]

38. Rusthoven, C.G.; Jones, B.L.; Flaig, T.W.; Crawford, E.D.; Koshy, M.; Sher, D.J.; Mahmood, U.; Chen, R.C.; Chapin, B.F.; Kavanagh, B.D.; et al. Improved Survival with Prostate Radiation in Addition to Androgen Deprivation Therapy for Men with Newly Diagnosed Metastatic Prostate Cancer. J. Clin. Oncol. 2016, 34, 2835-2842. [CrossRef] [PubMed]

39. Bruland, O.S.; Nilsson, S.; Fisher, D.R.; Larsen, R.H. High-linear energy transfer irradiation targeted to skeletal metastases by the alpha-emitter 223Ra: Adjuvant or alternative to conventional modalities? Clin. Cancer Res. 2006, 12, 6250s-6257s. [CrossRef] [PubMed]

40. Parker, C.; Nilsson, S.; Heinrich, D.; Helle, S.I.; O’Sullivan, J.M.; Fossa, S.D.; Chodacki, A.; Wiechno, P.; Logue, J.; Seke, M.; et al. Alpha emitter radium-223 and survival in metastatic prostate cancer. N. Engl. J. Med. 2013, 369, 213-223. [CrossRef] [PubMed]

41. Weichselbaum, R.R.; Hellman, S. Oligometastases revisited. Nat. Rev. Clin. Oncol. 2011, 8, 378-382. [CrossRef] [PubMed]

42. Berkovic, P.; De Meerleer, G.; Delrue, L.; Lambert, B.; Fonteyne, V.; Lumen, N.; Decaestecker, K.; Villeirs, G.; Vuye, P.; Ost, P. Salvage stereotactic body radiotherapy for patients with limited prostate cancer metastases: Deferring androgen deprivation therapy. Clin. Genitourin. Cancer 2013, 11, 27-32. [CrossRef] [PubMed]

43. Muacevic, A.; Kufeld, M.; Rist, C.; Wowra, B.; Stief, C.; Staehler, M. Safety and feasibility of image-guided robotic radiosurgery for patients with limited bone metastases of prostate cancer. Urol. Oncol. 2013, 31, 455-460. [CrossRef] [PubMed]

44. Muldermans, J.L.; Romak, L.B.; Kwon, E.D.; Park, S.S.; Olivier, K.R. Stereotactic Body Radiation Therapy for Oligometastatic Prostate Cancer. Int. J. Radiat. Oncol. Biol. Phys. 2016, 95, 696-702. [CrossRef] [PubMed]

45. Lawton, C.A.; Winter, K.; Murray, K.; Machtay, M.; Mesic, J.B.; Hanks, G.E.; Coughlin, C.T.; Pilepich, M.B. Updated results of the phase III Radiation Therapy Oncology Group (RTOG) trial 85-31 evaluating the potential benefit of androgen suppression following standard radiation therapy for unfavorable prognosis carcinoma of the prostate. Int. J. Radiat. Oncol. Biol. Phys. 2001, 49, 937-946. [CrossRef]

46. Pilepich, M.V.; Winter, K.; John, M.J.; Mesic, J.B.; Sause, W.; Rubin, P.; Lawton, C.; Machtay, M.; Grignon, D. Phase III radiation therapy oncology group (RTOG) trial 86-10 of androgen deprivation adjuvant to definitive radiotherapy in locally advanced carcinoma of the prostate. Int. J. Radiat. Oncol. Biol. Phys. 2001, 50, 1243-1252. [CrossRef]

47. D'Amico, A.V.; Chen, M.H.; Crook, J.; Armstrong, J.G.; Malone, S.; Steigler, A.; Dunne, M.; Kantoff, P.W.; Denham, J.W. Duration of short-course androgen suppression therapy and the risk of death as a result of prostate cancer. J. Clin. Oncol. 2011, 29, 4682-4687. [CrossRef] [PubMed]

48. Jones, C.U.; Hunt, D.; McGowan, D.G.; Amin, M.B.; Chetner, M.P.; Bruner, D.W.; Leibenhaut, M.H.; Husain, S.M.; Rotman, M.; Souhami, L.; et al. Radiotherapy and short-term androgen deprivation for localized prostate cancer. N. Engl. J. Med. 2011, 365, 107-118. [CrossRef] [PubMed]

49. Six Months Hormonal Treatment in Addition to Radiotherapy Improves Survival for Men with Localized Prostate Cancer. 2014. Available online: http://www.ascopost.com/News/16102 (accessed on 30 November 2016).

50. Pisansky, T.M.; Hunt, D.; Gomella, L.G.; Amin, M.B.; Balogh, A.G.; Chinn, D.M.; Seider, M.; Duclos, M.; Rosenthal, S.A.; Sandler, H.M. Radiation Therapy Oncology Group 9910: Phase 3 Trial to Evaluate the Duration of Neoadjuvant (NEO) Total Androgen Suppression (TAS) and Radiation Therapy (RT) in Intermediate-Risk Prostate Cancer (PCa). Int. J. Radiat. Oncol. Biol. Phys. 2013. [CrossRef] 
51. McGowan, D.G.; Hunt, D.; Jones, C.U.; Amin, M.; Leibenhaut, M.H.; Husain, S.M.; Rotman, M.; Souhami, L.; Sandler, H.; Shipley, W.U. Short-term Endocrine Therapy Prior to and during Radiation Therapy Improves Overall Survival in Patients with T1b-T2b Adenocarcinoma of the Prostate and PSA $\leq 20$ : Initial Results of RTOG 94-08. Int. J. Radiat. Oncol. Biol. Phys. 2010. [CrossRef]

52. Hanks, G.E.; Pajak, T.F.; Porter, A.; Grignon, D.; Brereton, H.; Venkatesan, V.; Horwitz, E.M.; Lawton, C.; Rosenthal, S.A.; Sandler, H.M.; et al. Phase III trial of long-term adjuvant androgen deprivation after neoadjuvant hormonal cytoreduction and radiotherapy in locally advanced carcinoma of the prostate: The Radiation Therapy Oncology Group Protocol 92-02. J. Clin. Oncol. 2003, 21, 3972-3978. [CrossRef] [PubMed]

53. Bolla, M.; de Reijke, T.M.; Van Tienhoven, G.; Van den Bergh, A.C.; Oddens, J.; Poortmans, P.M.; Gez, E.; Kil, P.; Akdas, A.; Soete, G.; et al. Duration of androgen suppression in the treatment of prostate cancer. N. Engl. J. Med. 2009, 360, 2516-2527. [CrossRef] [PubMed]

54. Nabid, A.; Carrier, N.; Martin, A.G.; Bahary, J.P.; Souhami, L.; Duclos, M.; Vincent, F.; Vass, S.; Bahoric, B.; Archambault, R.; et al. High-risk prostate cancer treated with pelvic radiotherapy and 36 versus 18 months of androgen blockade: Results of a phase III randomized study. J. Clin. Oncol. 2013, 31 (Suppl. S6), abstract 3.

55. Widmark, A.; Klepp, O.; Solberg, A.; Damber, J.E.; Angelsen, A.; Fransson, P.; Lund, J.A.; Tasdemir, I.; Hoyer, M.; Wiklund, F.; et al. Endocrine treatment, with or without radiotherapy, in locally advanced prostate cancer (SPCG-7/SFUO-3): An open randomised phase III trial. Lancet 2009, 373, 301-308. [CrossRef]

56. Warde, P.; Mason, M.; Ding, K.; Kirkbride, P.; Brundage, M.; Cowan, R.; Gospodarowicz, M.; Sanders, K.; Kostashuk, E.; Swanson, G.; et al. Combined androgen deprivation therapy and radiation therapy for locally advanced prostate cancer: A randomised, phase 3 trial. Lancet 2011, 378, 2104-2111. [CrossRef]

57. Mottet, N.; Peneau, M.; Mazeron, J.J.; Molinie, V.; Richaud, P. Addition of radiotherapy to long-term androgen deprivation in locally advanced prostate cancer: An open randomised phase 3 trial. Eur. Urol. 2012, 62, 213-219. [CrossRef] [PubMed]

58. Carrie, C.; Hasbini, A.; de Laroche, G.; Richaud, P.; Guerif, S.; Latorzeff, I.; Supiot, S.; Bosset, M.; Lagrange, J.L.; Beckendorf, V.; et al. Salvage radiotherapy with or without short-term hormone therapy for rising prostate-specific antigen concentration after radical prostatectomy (GETUG-AFU 16): A randomised, multicentre, open-label phase 3 trial. Lancet Oncol. 2016, 17, 747-756. [CrossRef]

59. Shipley, W.U.; Pugh, S.L.; Lukka, H.R.; Major, P.; Heney, N.M.; Grignon, D.A.; Sartor, O.; Patel, M.; Bahary, J.P.; Zietman, A.L.; et al. NRG Oncology/RTOG 9601, a phase III trial in prostate cancer patients: Anti-androgen therapy (AAT) with bicalutamide during and after salvage radiation therapy (RT) following radical prostatectomy (RP) and an elevated PSA. J. Clin. Oncol. 2016. [CrossRef]

60. Goodwin, J.F.; Schiewer, M.J.; Dean, J.L.; Schrecengost, R.S.; de Leeuw, R.; Han, S.; Ma, T.; Den, R.B.; Dicker, A.P.; Feng, F.Y.; et al. A hormone-DNA repair circuit governs the response to genotoxic insult. Cancer Discov. 2013, 3, 1254-1271. [CrossRef] [PubMed]

61. Polkinghorn, W.R.; Parker, J.S.; Lee, M.X.; Kass, E.M.; Spratt, D.E.; Iaquinta, P.J.; Arora, V.K.; Yen, W.F.; Cai, L.; Zheng, D.; et al. Androgen receptor signaling regulates DNA repair in prostate cancers. Cancer Discov. 2013, 3, 1245-1253. [CrossRef] [PubMed]

62. Milosevic, M.; Chung, P.; Parker, C.; Bristow, R.; Toi, A.; Panzarella, T.; Warde, P.; Catton, C.; Menard, C.; Bayley, A.; et al. Androgen withdrawal in patients reduces prostate cancer hypoxia: Implications for disease progression and radiation response. Cancer Res. 2007, 67, 6022-6025. [CrossRef] [PubMed]

63. Bristow, R.G.; Hill, R.P. Hypoxia and metabolism. Hypoxia, DNA repair and genetic instability. Nat. Rev. Cancer 2008, 8, 180-192. [CrossRef] [PubMed]

64. Milosevic, M.; Warde, P.; Menard, C.; Chung, P.; Toi, A.; Ishkanian, A.; McLean, M.; Pintilie, M.; Sykes, J.; Gospodarowicz, M.; et al. Tumor hypoxia predicts biochemical failure following radiotherapy for clinically localized prostate cancer. Clin. Cancer Res. 2012, 18, 2108-2114. [CrossRef] [PubMed]

65. Isaacs, J.T.; Lundmo, P.I.; Berges, R.; Martikainen, P.; Kyprianou, N.; English, H.F. Androgen regulation of programmed death of normal and malignant prostatic cells. J. Androl. 1992, 13, 457-464. [PubMed]

66. Roden, A.C.; Moser, M.T.; Tri, S.D.; Mercader, M.; Kuntz, S.M.; Dong, H.; Hurwitz, A.A.; McKean, D.J.; Celis, E.; Leibovich, B.C.; et al. Augmentation of T cell levels and responses induced by androgen deprivation. J. Immunol. 2004, 173, 6098-6108. [CrossRef] [PubMed]

67. Drake, C.G. Prostate cancer as a model for tumour immunotherapy. Nat. Rev. Immunol. 2010, 10, 580-593. [CrossRef] [PubMed] 
68. Kissick, H.T.; Sanda, M.G.; Dunn, L.K.; Pellegrini, K.L.; On, S.T.; Noel, J.K.; Arredouani, M.S. Androgens alter T-cell immunity by inhibiting T-helper 1 differentiation. Proc. Natl. Acad. Sci. USA 2014, 111, 9887-9892. [CrossRef] [PubMed]

69. Hussein, M.R.; Al-Assiri, M.; Musalam, A.O. Phenotypic characterization of the infiltrating immune cells in normal prostate, benign nodular prostatic hyperplasia and prostatic adenocarcinoma. Exp. Mol. Pathol. 2009, 86, 108-113. [CrossRef] [PubMed]

70. Gannot, G.; Richardson, A.M.; Rodriguez-Canales, J.; Pinto, P.A.; Merino, M.J.; Chuaqui, R.F.; Gillespie, J.W.; Emmert-Buck, M.R. Decrease in CD8+ lymphocyte number and altered cytokine profile in human prostate cancer. Am. J. Cancer Res. 2011, 1, 120-127. [PubMed]

71. McClinton, S.; Miller, I.D.; Eremin, O. An immunohistochemical characterisation of the inflammatory cell infiltrate in benign and malignant prostatic disease. Br. J. Cancer 1990, 61, 400-403. [CrossRef] [PubMed]

72. Kiniwa, Y.; Miyahara, Y.; Wang, H.Y.; Peng, W.; Peng, G.; Wheeler, T.M.; Thompson, T.C.; Old, L.J.; Wang, R.F. CD8+ Foxp3+ regulatory T cells mediate immunosuppression in prostate cancer. Clin. Cancer Res. 2007, 13, 6947-6958. [CrossRef] [PubMed]

73. Sfanos, K.S.; Bruno, T.C.; Maris, C.H.; Xu, L.; Thoburn, C.J.; DeMarzo, A.M.; Meeker, A.K.; Isaacs, W.B.; Drake, C.G. Phenotypic analysis of prostate-infiltrating lymphocytes reveals TH17 and Treg skewing. Clin. Cancer Res. 2008, 14, 3254-3261. [CrossRef]

74. Ebelt, K.; Babaryka, G.; Frankenberger, B.; Stief, C.G.; Eisenmenger, W.; Kirchner, T.; Schendel, D.; Noessner, E. Prostate cancer lesions are surrounded by FOXP3+, PD-1+ and B7-H1+ lymphocyte clusters. Eur. J. Cancer 2009, 45, 1664-1672. [CrossRef] [PubMed]

75. Vesalainen, S.; Lipponen, P.; Talja, M.; Syrjänen, K. Histological grade, perineural infiltration, tumour-infiltrating lymphocytes and apoptosis as determinants of long-term prognosis in prostatic adenocarcinoma. Eur. J. Cancer 1994, 30, 1797-1803. [CrossRef]

76. Gannon, P.O.; Poisson, A.O.; Delvoye, N.; Lapointe, R.; Mes-Masson, A.M.; Saad, F. Characterization of the intra-prostatic immune cell infiltration in androgen-deprived prostate cancer patients. J. Immunol. Methods 2009, 348, 9-17. [CrossRef] [PubMed]

77. Flammiger, A.; Bayer, F.; Cirugeda-Kühnert, A.; Huland, H.; Tennstedt, P.; Simon, R.; Minner, S.; Bokemeyer, C.; Sauter, G.; Schlomm, T.; et al. Intratumoral T but not B lymphocytes are related to clinical outcome in prostate cancer. APMIS 2012, 120, 901-908. [CrossRef] [PubMed]

78. Sorrentino, C.; Musiani, P.; Pompa, P.; Cipollone, G.; Di Carlo, E. Androgen deprivation boosts prostatic infiltration of cytotoxic and regulatory $\mathrm{T}$ lymphocytes and has no effect on disease-free survival in prostate cancer patients. Clin. Cancer Res. 2011, 17, 1571-1581. [CrossRef] [PubMed]

79. Fujii, T.; Shimada, K.; Asai, O.; Tanaka, N.; Fujimoto, K.; Hirao, K.; Konishi, N. Immunohistochemical analysis of inflammatory cells in benign and precancerous lesions and carcinoma of the prostate. Pathobiology 2013, 80, 119-126. [CrossRef] [PubMed]

80. Kärjä, V.; Aaltomaa, S.; Lipponen, P.; Isotalo, T.; Talja, M.; Mokka, R. Tumour-infiltrating lymphocytes: A prognostic factor of PSA-free survival in patients with local prostate carcinoma treated by radical prostatectomy. Anticancer Res. 2005, 25, 4435-4438. [PubMed]

81. Yuan, H.; Hsiao, Y.H.; Zhang, Y.; Wang, J.; Yin, C.; Shen, R.; Su, Y. Destructive impact of T-lymphocytes, NK and Mast cells on basal cell layers: Implications for tumor invasion. BMC Cancer 2013. [CrossRef] [PubMed]

82. Miller, A.M.; Lundberg, K.; Ozenci, V.; Banham, A.H.; Hellström, M.; Egevad, L.; Pisa, P. CD4+CD25high $\mathrm{T}$ cells are enriched in the tumor and peripheral blood of prostate cancer patients. J. Immunol. 2006, 177, 7398-7405. [CrossRef] [PubMed]

83. Seliger, B.; Stoehr, R.; Handke, D.; Mueller, A.; Ferrone, S.; Wullich, B.; Tannapfel, A.; Hofstaedter, F.; Hartmann, A. Association of HLA class I antigen abnormalities with disease progression and early recurrence in prostate cancer. Cancer Immunol. Immunother. 2010, 59, 529-540. [CrossRef] [PubMed]

84. Tan, H.; Bao, J.; Zhou, X. Genome-wide mutational spectra analysis reveals significant cancer-specific heterogeneity. Sci. Rep. 2015. [CrossRef] [PubMed]

85. Greenwald, R.J.; Latchman, Y.E.; Sharpe, A.H. Negative co-receptors on lymphocytes. Curr. Opin. Immunol. 2002, 14, 391-396. [CrossRef]

86. Latchman, Y.; Wood, C.R.; Chernova, T.; Chaudhary, D.; Borde, M.; Chernova, I.; Iwai, Y.; Long, A.J.; Brown, J.A.; Nunes, R.; et al. PD-L2 is a second ligand for PD-1 and inhibits T cell activation. Nat. Immunol. 2001, 2, 261-268. [CrossRef] [PubMed] 
87. Grosso, J.; Inzunza, D.; Wu, Q.; Simon, J.; Singh, P.; Zhang, X.; Phillips, T.; Simmons, P.; Cogswell, J. Programmed death-ligand 1 (PD-L1) expression in various tumor types. J. Immunother. Cancer 2013. [CrossRef]

88. Gevensleben, H.; Dietrich, D.; Golletz, C.; Steiner, S.; Jung, M.; Thiesler, T.; Majores, M.; Stein, J.; Uhl, B.; Müller, S.; et al. The Immune Checkpoint Regulator PD-L1 Is Highly Expressed in Aggressive Primary Prostate Cancer. Clin. Cancer Res. 2016, 22, 1969-1977. [CrossRef] [PubMed]

89. Graff, J.N.; Alumkal, J.J.; Drake, C.G.; Thomas, G.V.; Redmond, W.L.; Farhad, M.; Cetnar, J.P.; Ey, F.S.; Bergan, R.C.; Slottke, R.; et al. Early evidence of anti-PD-1 activity in enzalutamide-resistant prostate cancer. Oncotarget 2016, 25, 4-13. [CrossRef] [PubMed]

90. Vignali, D.A.; Collison, L.W.; Workman, C.J. How regulatory T cells work. Nat. Rev. Immunol. 2008, 8, 523-532. [CrossRef] [PubMed]

91. Idorn, M.; Kollgaard, T.; Kongsted, P.; Sengelov, L.; Thor Straten, P. Correlation between frequencies of blood monocytic myeloid-derived suppressor cells, regulatory $\mathrm{T}$ cells and negative prognostic markers in patients with castration-resistant metastatic prostate cancer. Cancer Immunol. Immunother. 2014, 63, 1177-1187. [CrossRef] [PubMed]

92. De Palma, M.; Lewis, C.E. Macrophage regulation of tumor responses to anticancer therapies. Cancer Cell 2013, 23, 277-286. [CrossRef] [PubMed]

93. Sousa, S.; Maatta, J. The role of tumour-associated macrophages in bone metastasis. J. Bone Oncol. 2016, 5, 135-138. [CrossRef] [PubMed]

94. Nonomura, N.; Takayama, H.; Nakayama, M.; Nakai, Y.; Kawashima, A.; Mukai, M.; Nagahara, A.; Aozasa, K.; Tsujimura, A. Infiltration of tumour-associated macrophages in prostate biopsy specimens is predictive of disease progression after hormonal therapy for prostate cancer. BJU Int. 2011, 107, 1918-1922. [CrossRef] [PubMed]

95. Shalapour, S.; Font-Burgada, J.; Di Caro, G.; Zhong, Z.; Sanchez-Lopez, E.; Dhar, D.; Willimsky, G.; Ammirante, M.; Strasner, A.; Hansel, D.E.; et al. Immunosuppressive plasma cells impede T-cell-dependent immunogenic chemotherapy. Nature 2015, 521, 94-98. [CrossRef] [PubMed]

96. Ammirante, M.; Luo, J.L.; Grivennikov, S.; Nedospasov, S.; Karin, M. B-cell-derived lymphotoxin promotes castration-resistant prostate cancer. Nature 2010, 464, 302-305. [CrossRef] [PubMed]

97. Kroeger, D.R.; Milne, K.; Nelson, B.H. Tumor-Infiltrating Plasma Cells Are Associated with Tertiary Lymphoid Structures, Cytolytic T-Cell Responses, and Superior Prognosis in Ovarian Cancer. Clin. Cancer Res. 2016, 22, 3005-3015. [CrossRef]

98. Hargadon, K.M. Tumor-altered dendritic cell function: Implications for anti-tumor immunity. Front. Immunol. 2013. [CrossRef] [PubMed]

99. Miller, A.M.; Pisa, P. Tumor escape mechanisms in prostate cancer. Cancer Immunol. Immunother. 2007, 56, 81-87. [CrossRef] [PubMed]

100. Aalamian, M.; Tourkova, I.L.; Chatta, G.S.; Lilja, H.; Huland, E.; Huland, H.; Shurin, G.V.; Shurin, M.R. Inhibition of dendropoiesis by tumor derived and purified prostate specific antigen. J. Urol. 2003, 170, 2026-2030. [CrossRef] [PubMed]

101. Morse, M.D.; McNeel, D.G. Prostate cancer patients on androgen deprivation therapy develop persistent changes in adaptive immune responses. Hum. Immunol. 2010, 71, 496-504. [CrossRef] [PubMed]

102. Lai, J.J.; Lai, K.P.; Zeng, W.; Chuang, K.H.; Altuwaijri, S.; Chang, C. Androgen receptor influences on body defense system via modulation of innate and adaptive immune systems: Lessons from conditional AR knockout mice. Am. J. Pathol. 2012, 181, 1504-1512. [CrossRef] [PubMed]

103. Drake, C.G.; Doody, A.D.; Mihalyo, M.A.; Huang, C.T.; Kelleher, E.; Ravi, S.; Hipkiss, E.L.; Flies, D.B.; Kennedy, E.P.; Long, M.; et al. Androgen ablation mitigates tolerance to a prostate/prostate cancer-restricted antigen. Cancer Cell 2005, 7, 239-249. [CrossRef] [PubMed]

104. Morse, M.D.; McNeel, D.G. T cells localized to the androgen-deprived prostate are TH1 and TH17 biased. Prostate 2012, 72, 1239-1247. [CrossRef] [PubMed]

105. Tang, S.; Moore, M.L.; Grayson, J.M.; Dubey, P. Increased CD8+ T-cell function following castration and immunization is countered by parallel expansion of regulatory T cells. Cancer Res. 2012, 72, 1975-1985. [CrossRef] 
106. Escamilla, J.; Schokrpur, S.; Liu, C.; Priceman, S.J.; Moughon, D.; Jiang, Z.; Pouliot, F.; Magyar, C.; Sung, J.L.; $\mathrm{Xu}$, J.; et al. CSF1 receptor targeting in prostate cancer reverses macrophage-mediated resistance to androgen blockade therapy. Cancer Res. 2015, 75, 950-962. [CrossRef] [PubMed]

107. Pu, Y.; Xu, M.; Liang, Y.; Yang, K.; Guo, Y.; Yang, X.; Fu, Y.X. Androgen receptor antagonists compromise $\mathrm{T}$ cell response against prostate cancer leading to early tumor relapse. Sci. Transl. Med. 2016. [CrossRef] [PubMed]

108. Reits, E.A.; Hodge, J.W.; Herberts, C.A.; Groothuis, T.A.; Chakraborty, M.; Wansley, E.K.; Camphausen, K.; Luiten, R.M.; de Ru, A.H.; Neijssen, J.; et al. Radiation modulates the peptide repertoire, enhances MHC class I expression, and induces successful antitumor immunotherapy. J. Exp. Med. 2006, 203, 1259-1271. [CrossRef] [PubMed]

109. Hong, J.H.; Chiang, C.S.; Tsao, C.Y.; Lin, P.Y.; McBride, W.H.; Wu, C.J. Rapid induction of cytokine gene expression in the lung after single and fractionated doses of radiation. Int. J. Radiat. Biol. 1999, 75, 1421-1427. [PubMed]

110. Friedman, E.J. Immune modulation by ionizing radiation and its implications for cancer immunotherapy. Curr. Pharm. Des. 2002, 8, 1765-1780. [CrossRef] [PubMed]

111. Obeid, M.; Panaretakis, T.; Joza, N.; Tufi, R.; Tesniere, A.; van Endert, P.; Zitvogel, L.; Kroemer, G. Calreticulin exposure is required for the immunogenicity of gamma-irradiation and UVC light-induced apoptosis. Cell Death Differ. 2007, 14, 1848-1850. [CrossRef] [PubMed]

112. Matsumura, S.; Wang, B.; Kawashima, N.; Braunstein, S.; Badura, M.; Cameron, T.O.; Babb, J.S.; Schenider, R.J.; Formenti, S.C.; Dustin, M.L.; et al. Radiation-induced CXCL16 release by breast cancer cells attracts effector T cells. J. Immunol. 2008, 181, 3099-3107. [CrossRef] [PubMed]

113. Sologuren, I.; Rodríguez-Gallego, C.; Lara, P.C. Immune effects of high dose radiation treatment: Implications of ionizing radiation on the development of bystander and abscopal effects. Transl. Cancer Res. 2014, 3, 18-31.

114. Voronov, E.; Shouval, D.S.; Krelin, Y.; Cagnano, E.; Benharroch, D.; Iwakura, Y.; Dinarello, C.A.; Apte, R.N. IL-1 is required for tumor invasiveness and angiogenesis. Proc. Natl. Acad. Sci. USA 2003, 100, 2645-2650. [CrossRef] [PubMed]

115. Warzocha, K.; Salles, G.; Bienvenu, J.; Bastion, Y.; Dumontet, C.; Renard, N.; Neidhardt-Berard, E.M.; Coiffier, B. Tumor necrosis factor ligand-receptor system can predict treatment outcome in lymphoma patients. J. Clin. Oncol. 1997, 15, 499-508. [PubMed]

116. Xu, J.; Escamilla, J.; Mok, S.; David, J.; Priceman, S.; West, B.; Bollag, G.; McBride, W.; Wu, L. CSF1R signaling blockade stanches tumor-infiltrating myeloid cells and improves the efficacy of radiotherapy in prostate cancer. Cancer Res. 2013, 73, 2782-2794. [CrossRef] [PubMed]

117. Barcellos-Hoff, M.H.; Derynck, R.; Tsang, M.L.; Weatherbee, J.A. Transforming growth factor-beta activation in irradiated murine mammary gland. J. Clin. Investig. 1994, 93, 892-899. [CrossRef] [PubMed]

118. Webb, J.R.; Milne, K.; Watson, P.; Deleeuw, R.J.; Nelson, B.H. Tumor-infiltrating lymphocytes expressing the tissue resident memory marker CD103 are associated with increased survival in high-grade serous ovarian cancer. Clin. Cancer Res. 2014, 20, 434-444. [CrossRef] [PubMed]

119. Djenidi, F.; Adam, J.; Goubar, A.; Durgeau, A.; Meurice, G.; de Montpréville, V.; Validire, P.; Besse, B.; Mami-Chouaib, F. CD8+CD103+ tumor-infiltrating lymphocytes are tumor-specific tissue-resident memory $\mathrm{T}$ cells and a prognostic factor for survival in lung cancer patients. J. Immunol. 2015, 194, 3475-3486. [CrossRef] [PubMed]

120. Wang, Z.Q.; Milne, K.; Derocher, H.; Webb, J.R.; Nelson, B.H.; Watson, P.H. CD103 and Intratumoral Immune Response in Breast Cancer. Clin. Cancer Res. 2016, 22, 6290-6297. [CrossRef] [PubMed]

121. Koh, Y.T.; Gray, A.; Higgins, S.A.; Hubby, B.; Kast, W.M. Androgen ablation augments prostate cancer vaccine immunogenicity only when applied after immunization. Prostate 2009, 69, 571-584. [CrossRef] [PubMed]

122. Graff, J.N.; Drake, C.G.; Beer, T.M. Complete biochemical (prostate-specific antigen) response to sipuleucel-T with enzalutamide in castration-resistant prostate cancer: A case report with implications for future research. Urology 2013, 81, 381-383. [CrossRef] [PubMed]

123. Ehlers, G.; Fridman, M. Abscopal effect of radiation in papillary adenocarcinoma. Br. J. Radiol. 1973, 46, 220-222. [CrossRef] [PubMed]

124. Robin, H.I.; AuBuchon, J.; Varanasi, V.R.; Weinstein, A.B. The abscopal effect: Demonstration in lymphomatous involvement of kidneys. Med. Pediatr. Oncol. 1981, 9, 473-476. [CrossRef] [PubMed] 
125. Wersäll, P.J.; Blomgren, H.; Pisa, P.; Lax, I.; Kälkner, K.M.; Svedman, C. Regression of non-irradiated metastases after extracranial stereotactic radiotherapy in metastatic renal cell carcinoma. Acta Oncol. 2006, 45, 493-497. [CrossRef] [PubMed]

126. Nakanishi, M.; Chuma, M.; Hige, S.; Asaka, M. Abscopal effect on hepatocellular carcinoma. Am. J. Gastroenterol. 2008, 103, 1320-1321. [CrossRef] [PubMed]

127. Okuma, K.; Yamashita, H.; Niibe, Y.; Hayakawa, K.; Nakagawa, K. Abscopal effect of radiation on lung metastases of hepatocellular carcinoma: A case report. J. Med. Case Rep. 2011. [CrossRef] [PubMed]

128. Stamell, E.F.; Wolchok, J.D.; Gnjatic, S.; Lee, N.Y.; Brownell, I. The abscopal effect associated with a systemic anti-melanoma immune response. Int. J. Radiat. Oncol. Biol. Phys. 2013, 85, 293-295. [CrossRef] [PubMed]

129. Postow, M.A.; Callahan, M.K.; Barker, C.A.; Yamada, Y.; Yuan, J.; Kitano, S.; Mu, Z.; Rasalan, T.; Adamow, M.; Ritter, E.; et al. Immunologic correlates of the abscopal effect in a patient with melanoma. N. Engl. J. Med. 2012, 366, 925-931. [CrossRef] [PubMed]

130. Grimaldi, A.M.; Simeone, E.; Giannarelli, D.; Muto, P.; Falivene, S.; Borzillo, V.; Giugliano, F.M.; Sandomenico, F.; Petrillo, A.; Curvietto, M.; et al. Abscopal effects of radiotherapy on advanced melanoma patients who progressed after ipilimumab immunotherapy. Oncoimmunology 2014. [CrossRef] [PubMed]

131. Demaria, S.; Ng, B.; Devitt, M.L.; Babb, J.S.; Kawashima, N.; Liebes, L.; Formenti, S.C. Ionizing radiation inhibition of distant untreated tumors (abscopal effect) is immune mediated. Int. J. Radiat. Oncol. Biol. Phys. 2004, 58, 862-870. [CrossRef] [PubMed]

132. Demaria, S.; Kawashima, N.; Yang, A.M.; Devitt, M.L.; Babb, J.S.; Allison, J.P.; Formenti, S.C. Immune-mediated inhibition of metastases after treatment with local radiation and CTLA-4 blockade in a mouse model of breast cancer. Clin. Cancer Res. 2005, 11, 728-734. [PubMed]

133. Dewan, M.Z.; Galloway, A.E.; Kawashima, N.; Dewyngaert, J.K.; Babb, J.S.; Formenti, S.C.; Demaria, S. Fractionated but not single-dose radiotherapy induces an immune-mediated abscopal effect when combined with anti-CTLA-4 antibody. Clin. Cancer Res. 2009, 15, 5379-5388. [CrossRef] [PubMed]

134. Hodge, J.W.; Sharp, H.J.; Gameiro, S.R. Abscopal regression of antigen disparate tumors by antigen cascade after systemic tumor vaccination in combination with local tumor radiation. Cancer Biother. Radiopharm. 2012, 27, 12-22. [CrossRef] [PubMed]

135. Nesslinger, N.J.; Sahota, R.A.; Stone, B.; Johnson, K.; Chima, N.; King, C.; Rasmussen, D.; Bishop, D.; Rennie, P.S.; Gleave, M.; et al. Standard treatments induce antigen-specific immune responses in prostate cancer. Clin. Cancer Res. 2007, 13, 1493-1502. [CrossRef] [PubMed]

136. Cho, Y.; Chang, J.S.; Rha, K.H.; Hong, S.J.; Choi, Y.D.; Ham, W.S.; Kim, J.W.; Cho, J. Does Radiotherapy for the Primary Tumor Benefit Prostate Cancer Patients with Distant Metastasis at Initial Diagnosis? PLoS ONE 2016, 11, e0147191. [CrossRef] [PubMed]

137. NCT01957436-A Phase III of ADT + / - Docetaxel + / - Local RT + / - Abiraterone Acetate in Metastatic Hormone-naïve Prostate Cancer. (PEACE1). Available online: https://clinicaltrials.gov/ct2/show/ NCT01957436 (accessed on 30 November 2016).

138. NCT00268476 -STAMPEDE: Systemic Therapy in Advancing or Metastatic Prostate Cancer: Evaluation of Drug Efficacy: A Multi-Stage Multi-Arm Randomised Controlled Trial (STAMPEDE). Available online: https:/ / clinicaltrials.gov/ct2/show/NCT00268476 (accessed on 30 November 2016).

139. ISRCTN06890529-A Randomised Study about the Effect on Survival of Hormonal Therapy versus Hormonal Therapy Plus Local External Radiation Therapy in Patients with Primary Diagnosed Metastasised (M+) Prostate Cancer. Available online: http:/ / www.isrctn.com/ISRCTN06890529 (accessed on 30 November 2016).

140. Kantoff, P.W.; Higano, C.S.; Shore, N.D.; Berger, E.R.; Small, E.J.; Penson, D.F.; Redfern, C.H.; Ferrari, A.C.; Dreicer, R.; Sims, R.B.; et al. Sipuleucel-T immunotherapy for castration-resistant prostate cancer. N. Engl. J. Med. 2010, 363, 411-422. [CrossRef] [PubMed]

141. Yi, D.H.; Appel, S. Current status and future perspectives of dendritic cell-based cancer immunotherapy. Scand. J. Immunol. 2013, 78, 167-171. [CrossRef] [PubMed]

142. NCT01807065-Sipuleucel-T With or Without Radiation Therapy in Treating Patients With Hormone-Resistant Metastatic Prostate Cancer. Available online: https://clinicaltrials.gov/ct2/ show / NCT01807065 (accessed on 30 November 2016). 
143. NCT01818986-Sipuleucel-T and Stereotactic Ablative Body Radiation (SABR) for Metastatic Castrate-resistant Prostate Cancer (mCRPC). Available online: https://clinicaltrials.gov/ct2/show/ NCT01818986 (accessed on 30 November 2016).

144. NCT02463799-Ph 2 Study of Sipuleucel-T W/ or W/O Radium-223 in Men with Asymptomatic or Minimally Symptomatic Bone-MCRPC. Available online: https://clinicaltrials.gov/ct2/show /NCT02463799 (accessed on 30 November 2016).

145. NCT02232230-A Multicenter Trial Enrolling Men With Advanced Prostate Cancer Who Are to Receive Combination Radiation and Sipuleucel-T. Available online: https://clinicaltrials.gov/ct2/show/ NCT02232230 (accessed on 30 November 2016).

146. Finkelstein, S.E.; Rodriguez, F.; Dunn, M.; Farmello, M.J.; Smilee, R.; Janssen, W.; Kang, L.; Chuang, T.; Seigne, J.; Pow-Sang, J.; et al. Serial assessment of lymphocytes and apoptosis in the prostate during coordinated intraprostatic dendritic cell injection and radiotherapy. Immunotherapy 2012, 4, 373-382. [CrossRef] [PubMed]

147. Hodge, J.W.; Sabzevari, H.; Yafal, A.G.; Gritz, L.; Lorenz, M.G.; Schlom, J. A triad of costimulatory molecules synergize to amplify T-cell activation. Cancer Res. 1999, 59, 5800-5807. [PubMed]

148. Marshall, J.L.; Gulley, J.L.; Arlen, P.M.; Beetham, P.K.; Tsang, K.Y.; Slack, R.; Hodge, J.W.; Doren, S.; Grosenbach, D.W.; Hwang, J.; et al. Phase I study of sequential vaccinations with fowlpox-CEA(6D)-TRICOM alone and sequentially with vaccinia-CEA(6D)-TRICOM, with and without granulocyte-macrophage colony-stimulating factor, in patients with carcinoembryonic antigen-expressing carcinomas. J. Clin. Oncol. 2005, 23, 720-731. [CrossRef] [PubMed]

149. Morse, M.A.; Clay, T.M.; Hobeika, A.C.; Osada, T.; Khan, S.; Chui, S.; Niedzwiecki, D.; Panicali, D.; Schlom, J.; Lyerly, H.K. Phase I study of immunization with dendritic cells modified with fowlpox encoding carcinoembryonic antigen and costimulatory molecules. Clin. Cancer Res. 2005, 11, 3017-3024. [CrossRef]

150. Arlen, P.M.; Skarupa, L.; Pazdur, M.; Seetharam, M.; Tsang, K.Y.; Grosenbach, D.W.; Feldman, J.; Poole, D.J.; Litzinger, M.; Steinberg, S.M.; et al. Clinical safety of a viral vector based prostate cancer vaccine strategy. J. Urol. 2007, 178, 1515-1520. [CrossRef] [PubMed]

151. Gulley, J.L.; Arlen, P.M.; Madan, R.A.; Tsang, K.Y.; Pazdur, M.P.; Skarupa, L.; Jones, J.L.; Poole, D.J.; Higgins, J.P.; Hodge, J.W.; et al. Immunologic and prognostic factors associated with overall survival employing a poxviral-based PSA vaccine in metastatic castrate-resistant prostate cancer. Cancer Immunol. Immunother. 2010, 59, 663-674. [CrossRef] [PubMed]

152. Kantoff, P.W.; Schuetz, T.J.; Blumenstein, B.A.; Glode, L.M.; Bilhartz, D.L.; Wyand, M.; Manson, K.; Panicali, D.L.; Laus, R.; Schlom, J.; et al. Overall survival analysis of a phase II randomized controlled trial of a Poxviral-based PSA-targeted immunotherapy in metastatic castration-resistant prostate cancer. J. Clin. Oncol. 2010, 28, 1099-1105. [CrossRef]

153. Gulley, J.L.; Arlen, P.M.; Bastian, A.; Morin, S.; Marte, J.; Beetham, P.; Tsang, K.Y.; Yokokawa, J.; Hodge, J.W.; Ménard, C.; et al. Combining a recombinant cancer vaccine with standard definitive radiotherapy in patients with localized prostate cancer. Clin. Cancer Res. 2005, 11, 3353-3362. [CrossRef] [PubMed]

154. Lechleider, R.J.; Arlen, P.M.; Tsang, K.Y.; Steinberg, S.M.; Yokokawa, J.; Cereda, V.; Camphausen, K.; Schlom, J.; Dahut, W.L.; Gulley, J.L. Safety and immunologic response of a viral vaccine to prostate-specific antigen in combination with radiation therapy when metronomic-dose interleukin 2 is used as an adjuvant. Clin. Cancer Res. 2008, 14, 5284-5291. [CrossRef] [PubMed]

155. Heery, C.R.; Madan, R.A.; Stein, M.N.; Stadler, W.M.; Di Paola, R.S.; Rauckhorst, M.; Steinberg, S.M.; Marté, J.L.; Chen, C.C.; Grenga, I.; et al. Samarium-153-EDTMP (Quadramet(R)) with or without vaccine in metastatic castration-resistant prostate cancer: A randomized Phase 2 trial. Oncotarget 2016, 7, 69014-69023. [CrossRef] [PubMed]

156. Kwon, E.D.; Drake, C.G.; Scher, H.I.; Fizazi, K.; Bossi, A.; van den Eertwegh, A.J.; Krainer, M.; Houede, N.; Santos, R.; Mahammedi, H.; et al. Ipilimumab versus placebo after radiotherapy in patients with metastatic castration-resistant prostate cancer that had progressed after docetaxel chemotherapy (CA184-043): A multicentre, randomised, double-blind, phase 3 trial. Lancet Oncol. 2014, 15, 700-712. [CrossRef]

157. Borghaei, H.; Paz-Ares, L.; Horn, L.; Spigel, D.R.; Steins, M.; Ready, N.E.; Chow, L.Q.; Vokes, E.E.; Felip, E.; Holgado, E.; et al. Nivolumab versus Docetaxel in Advanced Nonsquamous Non-Small-Cell Lung Cancer. N. Engl. J. Med. 2015, 373, 1627-1639. [CrossRef] [PubMed] 
158. Brahmer, J.; Reckamp, K.L.; Baas, P.; Crinò, L.; Eberhardt, W.E.; Poddubskaya, E.; Antonia, S.; Pluzanski, A.; Vokes, E.E.; Holgado, E.; et al. Nivolumab versus Docetaxel in Advanced Squamous-Cell Non-Small-Cell Lung Cancer. N. Engl. J. Med. 2015, 373, 123-135. [CrossRef] [PubMed]

159. Robert, C.; Schachter, J.; Long, G.V.; Arance, A.; Grob, J.J.; Mortier, L.; Daud, A.; Carlino, M.S.; McNeil, C.; Lotem, M.; et al. Pembrolizumab versus Ipilimumab in Advanced Melanoma. N. Engl. J. Med. 2015, 372, 2521-2532. [CrossRef] [PubMed]

160. Weber, J.S.; D'Angelo, S.P.; Minor, D.; Hodi, F.S.; Gutzmer, R.; Neyns, B.; Hoeller, C.; Khushalani, N.I.; Miller, W.H., Jr.; Lao, C.D.; et al. Nivolumab versus chemotherapy in patients with advanced melanoma who progressed after anti-CTLA-4 treatment (CheckMate 037): A randomised, controlled, open-label, phase 3 trial. Lancet Oncol. 2015, 16, 375-384. [CrossRef]

161. Garon, E.B.; Rizvi, N.A.; Hui, R.; Leighl, N.; Balmanoukian, A.S.; Eder, J.P.; Patnaik, A.; Aggarwal, C.; Gubens, M.; Horn, L.; et al. Pembrolizumab for the treatment of non-small-cell lung cancer. N. Engl. J. Med. 2015, 372, 2018-2028. [CrossRef] [PubMed]

162. NCT02861573 - Study of Pembrolizumab (MK-3475) Combination Therapies in Metastatic Castration-Resistant Prostate Cancer (MK-3475-365/KEYNOTE-365). Available online: https: / / clinicaltrials.gov/ct2/show/NCT02861573 (accessed on 30 November 2016).

163. NCT02312557-Pembrolizumab in Treating Patients with Metastatic Castration Resistant Prostate Cancer Previously Treated With Enzalutamide. Available online: https://clinicaltrials.gov/ct2/show/NCT02312557 (accessed on 30 November 2016).

164. NCT02787005—Study of Pembrolizumab (MK-3475) in NCT02787005-Study of Pembrolizumab (MK-3475) in Participants with Metastatic Castration-Resistant Prostate Cancer (mCRPC) Previously Treated with Chemotherapy (MK-3475-199/KEYNOTE-199). Available online: https://clinicaltrials.gov/ct2/show/ NCT02787005/ (accessed on 30 November 2016).

165. Finkelstein, S.E.; Fishman, M. Clinical opportunities in combining immunotherapy with radiation therapy. Front. Oncol. 2012. [CrossRef] [PubMed]

166. Schaue, D.; Ratikan, J.A.; Iwamoto, K.S.; McBride, W.H. Maximizing tumor immunity with fractionated radiation. Int. J. Radiat. Oncol. Biol. Phys. 2012, 83, 1306-1310. [CrossRef] [PubMed]

167. Lugade, A.A.; Moran, J.P.; Gerber, S.A.; Rose, R.C.; Frelinger, J.G.; Lord, E.M. Local radiation therapy of B16 melanoma tumors increases the generation of tumor antigen-specific effector cells that traffic to the tumor. J. Immunol. 2005, 174, 7516-7523. [CrossRef] [PubMed]

168. Lee, Y.; Auh, S.L.; Wang, Y.; Burnette, B.; Wang, Y.; Meng, Y.; Beckett, M.; Sharma, R.; Chin, R.; Tu, T.; et al. Therapeutic effects of ablative radiation on local tumor require CD8+ T cells: Changing strategies for cancer treatment. Blood 2009, 114, 589-595. [CrossRef] [PubMed]

169. NCT02107430-Phase II Study of DCVAC/PCa after Primary Radiotherapy for Patients with High Risk Localized Prostate Cancer. Available online: https://clinicaltrials.gov/ct2/show/NCT02107430 (accessed on 30 November 2016).

170. NCT00323882 - Study of MDX-010 in Patients with Metastatic Hormone-Refractory Prostate Cancer. Available online: https:/ / clinicaltrials.gov/ct2/show/NCT00323882 (accessed on 30 November 2016).

171. NCT00861614 - Study of Immunotherapy to Treat Advanced Prostate Cancer. Available online: https: / / clinicaltrials.gov /ct2/show / NCT00861614 (accessed on 30 November 2016).

172. NCT01777802-Monitoring Anti-Prostate Cancer Immunity Following Stereotactic Body Radiotherapy (SBRT) (SBRT). Available online: https://clinicaltrials.gov/ct2/show/NCT01777802 (accessed on 30 November 2016).

173. NCT01436968 - Phase 3 Study of ProstAtak ${ }^{\circledR}$ Immunotherapy with Standard Radiation Therapy for Localized Prostate Cancer (PrTK03). Available online: https://www.clinicaltrials.gov/ct2/show/ NCT01436968 (accessed on 30 November 2016).

174. NCT00005916-PSA-Based Vaccine and Radiotherapy to Treat Localized Prostate Cancer. Available online: https:/ clinicaltrials.gov/ct2/show/NCT00005916 (accessed on 30 November 2016).

175. NCT00450619-153Sm-EDTMP with or without a PSA/TRICOM Vaccine To Treat Men With Androgen-Insensitive Prostate Cancer. Available online: https://clinicaltrials.gov/ct2/show /NCT00450619 (accessed on 30 November 2016).

176. NCT01496131-Tecemotide (L-BLP25) in Prostate Cancer. Available online: https://clinicaltrials.gov/ct2/ show/NCT01496131 (accessed on 30 November 2016). 
177. Young, K.H.; Baird, J.R.; Savage, T.; Cottam, B.; Friedman, D.; Bambina, S.; Messenheimer, D.J.; Fox, B.; Newell, P.; Bahjat, K.S.; et al. Optimizing Timing of Immunotherapy Improves Control of Tumors by Hypofractionated Radiation Therapy. PLoS ONE 2016, 11, e0157164. [CrossRef] [PubMed]

178. Dovedi, S.J.; Adlard, A.L.; Lipowska-Bhalla, G.; McKenna, C.; Jones, S.; Cheadle, E.J.; Stratford, I.J.; Poon, E.; Morrow, M.; Stewart, R.; et al. Acquired resistance to fractionated radiotherapy can be overcome by concurrent PD-L1 blockade. Cancer Res. 2014, 74, 5458-5468. [CrossRef] [PubMed]

179. Finkelstein, S.E.; Iclozan, C.; Bui, M.M.; Cotter, M.J.; Ramakrishnan, R.; Ahmed, J.; Noyes, D.R.; Cheong, D.; Gonzalez, R.J.; Heysek, R.V.; et al. Combination of external beam radiotherapy (EBRT) with intratumoral injection of dendritic cells as neo-adjuvant treatment of high-risk soft tissue sarcoma patients. Int. J. Radiat. Oncol. Biol. Phys. 2012, 82, 924-932. [CrossRef] [PubMed]

180. Navarro, D.; Luzardo, O.P.; Fernández, L.; Chesa, N.; Díaz-Chico, B.N. Transition to androgen-independence in prostate cancer. J. Steroid. Biochem. Mol. Biol. 2002, 81, 191-201. [CrossRef]

181. Chang, L.; Graham, P.H.; Hao, J.; Bucci, J.; Cozzi, P.J.; Kearsley, J.H.; Li, Y. Emerging roles of radioresistance in prostate cancer metastasis and radiation therapy. Cancer Metastasis Rev. 2014, 33, 469-496. [CrossRef] [PubMed]

182. Harris, T.J.; Hipkiss, E.L.; Borzillary, S.; Wada, S.; Grosso, J.F.; Yen, H.R.; Getnet, D.; Bruno, T.C.; Goldberg, M.V.; Pardoll, D.M.; et al. Radiotherapy augments the immune response to prostate cancer in a time-dependent manner. Prostate 2008, 68, 1319-1329. [CrossRef]

183. Garg, A.D.; Galluzzi, L.; Apetoh, L.; Baert, T.; Birge, R.B.; Bravo-San Pedro, J.M.; Breckpot, K.; Brough, D.; Chaurio, R.; Cirone, M.; et al. Molecular and Translational Classifications of DAMPs in Immunogenic Cell Death. Front. Immunol. 2015. [CrossRef] [PubMed]

184. Demaria, S.; Formenti, S.C. Can abscopal effects of local radiotherapy be predicted by modeling $\mathrm{T}$ cell trafficking? J. Immunother. Cancer 2016. [CrossRef]

(C) 2017 by the authors; licensee MDPI, Basel, Switzerland. This article is an open access article distributed under the terms and conditions of the Creative Commons Attribution (CC BY) license (http:/ / creativecommons.org/licenses/by/4.0/). 